\title{
Ovarian Biomarkers in Infertility
}

\author{
Ivailo Vangelov, Julieta Dineva, Krassimira Todorova, \\ Soren Hayrabedyan and Maria D. Ivanova \\ Institute of Biology and Immunology of Reproduction "Acad. K. Bratanov", \\ Bulgarian Academy of Sciences, \\ Bulgaria
}

\section{Introduction}

The female infertility is a complex phenomenon that at least in part resides in the manifestation, possible perturbations and interplay of innate and adaptive immunity, with the participation of apoptotic and reactive oxygen species pathways, and some paracrine factors as causative and implementing factors in this process. The spread of the assisted reproduction technologies provided an unseen before opportunity to the intimacy of the ovarian follicle - the oocyte cellular surroundings and the oocyte itself, enabling research and medical community to boost the pursuit of new ovarian function biomarkers in the context of gamete fertilization and embryo development competence. The notion of infertility markers would be presented in a comprehensive viewpoint based on the importance of the folliculogenesis, oocyte-cumulus-granulosa cells interactions and oocyte genesis. This approach is aimed on the provision of non-invasive means for oocyte and embryo competence evaluation and improved reproductive medicine outcome.

\section{Autoimmunity and ovarian function impairment}

\subsection{Anti-ovarian antibodies and infertility}

The human ovary can be target of an autoimmune attack in various circumstances, including several organ-specific or systemic autoimmune diseases. One important issue concerning autoimmunity and infertility is the role of autoimmune responses against ovary, adrenal and thyroid glands in the development of premature ovarian failure.

Premature Ovarian Failure (POF) or Primary Ovarian Insufficiency (POI)) is the loss of function of the ovaries before age of 40 . It has been estimated that POF affects $1 \%$ of the population (Chatterjee et al., 2007). Hormonally, POF is defined by abnormally low levels of estrogen and high levels of follicle stimulating hormone (FSH), which demonstrate that the ovaries are no longer responding to circulating FSH by producing estrogen and developing fertile oocyte.

One of the reasons to suspect an autoimmune etiology of POF is the frequent association of POF with some organ-specific autoimmune diseases but the absence of associated disease cannot exclude an autoimmune mechanism. Among organ - specific autoimmune diseases, the thyroid and adrenal diseases (Addison's disease) are frequently associated with POF. In 
regard to association with adrenal autoimmunity (Addison's disease) three different situations have to be distinguished: POF associated with adrenal autoimmunity, POF associated with nonadrenal autoimmunity, and isolated or idiopathic POF (Forges et al., 2004). Among POF patients with adrenal autoimmunity 4-5\% are positive for autoantibodies directed against steroidogenic cytochrome $\mathrm{P} 450$ enzymes, such as 21-hydroxylase autoantibodies, 17a-hydroxylase autoantibodies and cholesterol side-chain cleavage enzyme (side-chain cleavage autoantibodies or steroid cell autoantibodies, SCAs)(Chen et al., 1996). Positivity for these autoantibodies identifies POF due to autoimmunity to steroid-producing cells - SCA-POF (Hoek et al., 1997, Betterle et al., 2002, Bakalov et al., 2005). In these patients the ovarian pathology has been associated with selective mononuclear cell infiltration of large antral follicles (Hoek et al., 1997) and with autoimmune destruction of theca cells (Welt et al 2005). The autoimmune damage of the ovarian theca cells and adrenal cortex are thought to be a T cell-mediated process (Hoek et al., 1997) as POF patients with adrenal autoimmunity have predominantly expressed IgG1 isotype SCA (Brozzetti et al., 2010). The predominant IgG1 isotype of the specific autoantibodies can be interpreted as a sign of Th1 immune response (Hawa et al., 2000). The presence of SCA is a risk factor for development of POF. Relatively higher percentage of women with normal menstrual cycle, who have polyendocrinopathy and SCA become susceptible to ovarian failure development within 815 years). The pathophysiological significance of SCA seems to be restricted to patients whose ovarian failure is associated with adrenal autoimmunity. These antibodies are very useful markers of ovarian failure in Addison's disease patients. In $90 \%$ of these patients at least one type of SCA can be detected (Falorni et al., 2002) whereas the prevalence of SCA in $<10 \%$ of cases has been detected in the patients with POF associated with nonadrenal autoimmunity and in the patients with idiopathic POF (Dal Pra et al., 2003).

On the other hand, two-thirds of women with recently diagnosed POF due to SCAassociated autoimmunity have normal serum Anti-Müllerian hormone (AMH) concentrations (La Marca et al., 2010). AMH is expressed by granulose luteinized cells (GLCs) of the ovary during the reproductive years, and controls the formation of primary follicles by inhibiting excessive follicular recruitment by FSH. It therefore, has a role in folliculogenesis and some authors suggest it is a measure of certain aspects of ovarian function (Broer 2011) and useful in assessing conditions such as polycystic ovary syndrome (PCOS) and POF. However, the normal AMH levels in women recently diagnosed for SCAPOF imply that this form of ovarian failure have association with a preserved pool of functioning follicles (La Marca et al., 2010). Indeed, in such patients this is selective autoimmune destruction of theca cells with preservation of GLCs that produce low amounts of estradiol because of lack of substrates. Therefore, the more exact term of this complication, as well as other forms of ovarian failure, would be primary ovarian insufficiency (POI) (Nelson 2009), since the term POI implies more appropriately the continuous nature of the impaired ovarian function.

Among systemic autoimmune diseases, the systemic lupus erithemathosus (SLE) is thought to be most frequently associated with POF (Hoek et al., 1997). Anti- corpus luteum antibodies could represent the first stage of altered ovarian function in SLE patients (Pasoto et al., 1999). An autoantigenic $67 \mathrm{kDa}$ target recognized by autoantibodies from $22 \%$ of patients $($ age $<40)$ with SLE has been described to correlate with elevated serum FSH levels. In general, anti ovarian antibodies (AOA) were found in $84 \%$ of the cases of female SLE patients (Moncayo-Naveda et al., 1989). 
Follicle dysfunction could be associated with inadequate follicular function, for example, due to mutated FSH- receptor gene (Doherty et al., 2002), but also due to autoimmune ovarian disease damaging the maturing follicles, but at the same time leaving the primordial follicles intact. In the majority of the cases, the cause of POF is unknown, but some of the causes can lead to absence of oocytes, whereas others can lead to disordered follicle maturation. However, several studies have suggested that some cases of POF could be a direct result of autoimmune-mediated damage of the ovaries (Hoek et al., 1997).

Strong support for an autoimmune character of isolated POF would be the presence of antibodies to ovarian structures or AOA in the serum of these patients. Evidence favors the presence of an autoimmune disease of the ovary. In some cases AOA has been considered to be a suitable marker for identification of autoimmune POF (Luborsky et al., 1990, 2000, Fénichel et al 1997, Pires et al., 2006) as well as immunological- related infertility in "in vitro" fertilization (IVF) patients (Gobert et al., 1992, Ivanova et al. 1994, 1999, Barbarino-Monnier et al., 2003, Pires et al, 2007). Screen for the presence of AOA before the initiation of the IVF cycle could be recommended, since AOA are thought to be associated with poor results in infertility patients included in the programs for assisted reproduction (Pires et al., 2007).

Other ovarian disturbances as Polycystic Ovarian Syndrome (PCOS), endometriosis, and unexplained infertility are associated with anti-ovarian autoimmunity. Approximately $15 \%$ to $30 \%$ of couples will be diagnosed with unexplained infertility after their diagnostic workup (Practice Committee of the American Society for Reproductive Medicine, 2006). The presence of AOA has been detected in patients with unexplained infertility (Luborsky et., al 1999, 2000, 2002). It has been demonstrated that AOA could be detected several months or years before the onset of the clinical symptoms without affecting the serum FSH or inhibin B levels (Luborsky et al 2000). Collectively these findings suggest that the AOA are independent markers for the future onset of ovarian failure.

PCOS is of clinical and public health importance as it is very common, affecting up to one in five women of reproductive age. The prevalence of PCOS depends on the choice of diagnostic criteria. One community-based prevalence study using the Rotterdam criteria found that about $18 \%$ of women had PCOS, and that $70 \%$ of them were previously undiagnosed (Teede et al., 2010). The association of ovarian autoimmunity with PCOS has been previously evaluated (Luborsky et al., 1999). It has been found that the frequency of AOA is similar $(25 \%)$ among the normally cycling women and PCOS patients. The possible development of humoral autoimmunity and production of AOA consequent to ovarian damage has also been determined in clomiphene citrate-resistant PCOS patients (Alborzi et al., 2009).

Autoimmunity to endometrium and ovary has been studied in patients with endometriosis (Mathur et al., 1982). It has been demonstrated the presence of elevated autoantibody titers to whole ovary, theca cells, granulosa cells and endometrium in the patient sera, and to GLCs in the cervical secretions. Endometriosis and PCOS have been associated with higher values of anti-FSH IgA autoantibodies, and endometriosis also has association with antiFSH IgG autoantibodies). One of the major epitopes identified was a 78-93 amino acid sequence belonging to part of the human FSH beta-chain (Gobert et al., 2001). This autoantigenic determinant is recognized most frequently by human serum samples from women with AOA. Anti-FSH are thought to be naturally occurring autoantibodies associated with peripheral FSH concentrations, but increased in infertile women with 
dysregulation of immune reactions and repeatedly performed in vitro fertilization (IVF) (Haller et al., 2005).

Significant progress was made towards the identification of candidate biomarkers involved in human ovarian autoimmunity. The presence of anti-oocyte antibodies has been demonstrated in the sera of POF patients (Damewood et al., 1986) with or without associated autoimmune diseases (Luborsky et al., 1990) and in the sera of infertile patients (Pires et al., 2006, 2007), as well as in mice after neonatal thymectomy (Tong \& Nelson 1999). In the mouse model of autoimmune ovarian failure, the autoantigenic oocyte protein has been identified and called Maternal Antigen That Embryos Require (MATER), (Tong \& Nelson, 1999). Using specific and sensitive immunoassays (Pires et al., 2007) demonstrated that AOA in infertile women identified an immunodominant antigen- heat shock protein 90 beta, which was localized predominantly in the oocyte cytoplasm. Therefore, anti-HSP90 antibodies could be used as one of the diagnostic markers for ovarian failure and thereby infertility (Pires et al., 2007).

Anti-Zona pellucida autoantibodies bind to the oocyte Zona pellucida (ZP), and therefore, could prevent sperm-zona interaction (Kyurkchiev et al., 1988, Barber \& Fayrer Hosken, 2000). Zona pellucida proteins play critical role in oocyte fertilization. Anti-ZP autoantibodies have been linked with human female infertility (Ivanova et al.1994, 1999, Mardesic et al., 2000, Kelkar et al., 2005, Koyama, 2010). Intra cytoplasmic sperm injection (ICSI) is recommended option for IVF therapy of women with anti-ZP autoantibodies (Mardesic et al., 2000). Anti- ZP autoantibodies may induce autoimmune-mediated ovarian damage with follicular depletion and fertility suppression due to impaired ZP formation (Lloyd et al., 2010) and disruption of the gap junctions between the oocyte and granulosa cells, damaging the bidirectional communication necessary for normal folliculogenesis (Calongos et al., 2009).

In addition, novel immunotherapy strategy has been proposed recently for treatment of autoimmune ovarian disease ( $\mathrm{Li}$ et al., 2008). The continuous presence of physiologicallyexpressed autoantigen is critical for both tolerance maintenance and autoimmune disease pathogenesis, thus the outcome is determined by the integrity of regulatory $\mathrm{T}$ cells, whereas deficiency in the regulatory T-cell function is associated with elevated responsiveness to autoantigen and to environmental stimuli that could potentially promote the autoimmune disease and memory (Tung et al., 2005). Sundblad et al., 2006 showed the presence of circulating autoantibodies directed towards an antigen of approximately $50 \mathrm{kDa}$, identified subsequently as alpha-enolase. It has been demonstrated that 21 of 110 women with autoimmune POF express this autoantibody, whereas 60 control subjects proved negative. Aldehyde (retinal) dehydrogenase 1A1 (ALDH1A1) and selenium-binding protein 1 (SBP1) are identified as unique autoantigenic targets associated with unexplained infertility (Edassery et al., 2010).

More recently, three immunodominant ovarian autoantigens, a-actinin 4 (aACTN4), heat shock 70 protein 5 (HSPA5) and $\beta$-actin (ACTB), have been identified using AOA -positive sera from women with idiopathic POF and women undergoing IVF (Mande et al., 2011). These autoantigens are localized in different structures of the ovary such as the ooplasm of the oocyte, theca, granulosa, corpus luteum and zona pellucida. All the above antigens were found to be expressed in the ooplasm throughout follicular development, and all of them were expressed specifically in the oocyte except aACTN4. Both women with infertility and 
those with ovarian cancer have autoantibodies to ovarian antigens. Luborsky et al., 2011 showed for the first time that antibodies to mesothelin, a well-characterized ovarian cancer antigen, occur in some of the women with epidemiologic risk for ovarian cancer.

The antibody-mediated autoreactivity directed towards the granulosa cells has been reported in the sera of POF patients (Damewood et al., 1986, Kelkar et al., 2005). AOA in POF patients showed immunoreactivity against the granulosa cells from both the pre-antral and the antral follicles (Damewood et al., 1986). In small percentage of the anti-ZP positive POF sera, a strong autoreactivity directed to granulosa cells has also been detected (Horejsi et al., 2000, Kelkar et al 2005). A $51 \mathrm{kDa}$ protein has been identified as an additional target of SCA (Winqvist et al., 1998). It has been localized in the placenta and in the GLCs by the sera of patients with adrenal insufficiency and associated ovarian failure.

We have developed an ELISA assay to assess the prevalence of anti-granulosa cell antibodies and we have estimated it to be $28.7 \%$ in the sera and $44.90 \%$ in the follicular fluids (FFls) of infertile patients undergoing controlled ovarian hyper-stimulations (COHS) for IVF-ET (embryo transfer) compared to $9.1 \%$ and $6.67 \%$ in the fertile women sera and FFls respectively (Vangelov et al., 2005,2006,2009).For the isolation of granulosa cells, pooled follicular fluids were collected individually for each patient, centrifuged at $200 \mathrm{x}$ g and purified using HISTOPAQUE® -1077 (Sigma Diagnostics, Inc.) gradient centrifugation approach (for details, see Vangelov et al., 2005). The results obtained by this ELISA assay disclosed that antibodies against granulosa cell-antigens occurred more frequently in infertile women undergoing IVF-ET than in fertile normally menstruating women (controls) at the same age, inferring to the conclusion that the detection of anti-granulosa cell antibodies serve as an indicator for their involvement in immunological infertility. Auto-antibodies against GLCs antigens may be considered as a part of the heterogeneous group of AOA (Ghazeeri \& Kutteh 2001). The prevalence of anti-granulosa cell autoantibodies in the subgroup with low fertilization rate suggests a negative impact of the anti-granulosa cell autoantibodies on the fertilization outcome. It was suggested that the binding of these antibodies to follicular cells might be a defective signal in the fertilization process (Horejsi et al., 2000). Anti-granulosa cell autoantibodies could play a role as a marker of fertilization failure.

In addition to the mentioned above, the identification of putative granulosa cell antigens recognizable by the antibodies in the infertile women sera, but not by the fertile controls sera is of huge importance. Four undefined GLC autoantigens - $110 \mathrm{kD}, 70-80 \mathrm{kD}, 47 \mathrm{kD}$ and 37 $\mathrm{kD}$ have been identified as autoantigenic targets for the anti-GLCs autoantibodies using immunoblotting assay developed by us (Vangelov et al., 2005). The results from immunoblotting revealed that: 3 patient's sera and none control sera reacted with protein band with MM $37 \mathrm{kD} ; 14$ patient's sera and 3 control sera - at $47 \mathrm{kD} ; 10$ patient's sera and 1 control serum - at 70-80 kD and 8 patient's sera and 3 control sera - at $110 \mathrm{kD}$. Four patient's sera reacted with all above protein bands. The band with approximate MM of $47 \mathrm{kD}$ was the most frequently occurring antigen in infertile women and the band of $37 \mathrm{kD}$ reacted only with sera from infertile patients studied.

\subsection{Cellular immunity, pro-inflammatory cytokines and apoptosis in infertility}

The diagnosis of an autoimmune mechanism involvement in infertile patients relies not only on the presence of autoantibodies directed to ovary, but also on the dynamics of immune cell populations and their soluble products. Natural killer cells (NK cells) constitute a major 
component of the innate immune system. NK cells have a suppressive action on B cells, and therefore, the impaired NK cell activity has a role in some types of autoimmunity. NK cell abnormalities have been reported in women with POF (Hoek et al., 1995) and in women with POI (van Kasteren et al., 2000), as well as in murine post-thymectomy autoimmune oophoritis (Maity et al 1997), all demonstrating a decreased NK cell number and/or activity. Similarly NK cells suppression is observed in neonatal thymectomy induced mice autoimmune oophoritis (Maity et al., 1997), while treatment by the NK cell-stimulating factor (IL-12) before thymectomy preserves the NK cell activity and ameliorates the associated autoimmune oophoritis. NK cells produce the signature Th1 cytokine IFN- $\gamma$. The increased periphery NK cell activity and number during pregnancy might explain the apparent Th1 bias (Ntrivalas et al., 2001) that is also associated with multiple observations of recurrent pregnancy losses (Piccinni et al., 1998, Prado-Drayer et al., 2008). These findings suggested an important role for the innate immune system. The immune activation might cause pregnancy failure by inhibiting the reproductive endocrine system. In this way, for example, the inflammatory cytokines are thought to inhibit both the gonadotropin production at hypothalamus and pituitary gland level (Rivest \& Rivier 1995), and the progesterone synthesis in corpus luteum of the ovary as well as to promote the luteal regression (Davis \& Rueda 2002). Monocytes (Mo) and the monocyte-derived dendritic cells (DCs) play a prominent role in the initial stages of autoimmune reactions against endocrine organs. The accumulation of monocytes/DCs and the clustering of DCs in endocrine organs is one of the first sign of an autoimmune endocrine disorder. Mo start to replace the resident Macrophages (Ma) and DCs under normal state and in response to inflammation signals, they move in the tissue vicinities and proliferate and differentiate into Ma and DCs. The main function of DCs is to act as antigen presenting cells, being messengers between the innate and adaptive immunity. Immature DCs are found in the bloodstream, but once activated, they migrate to the lymph nodes where they interact with T- and B -cells to initiate and shape the adaptive immune response. Dysfunction of Mo and DCs has been found in patients with ovarian failure (Hoek et al., 1993) long enough - the Mo have abnormal polarization and DCs have abnormal interaction with $\mathrm{T}$-cells, refractive to estrogen substitution correction. Alteration of $\mathrm{T}$ cell subsets and $\mathrm{T}$ cell mediated injury is likely to play an important role in pathogenesis of autoimmune ovarian failure as evidenced by human studies and animal models of autoimmune oophoritis (Hoek et al., 1995, Mignot et al., 1989b, van Kasteren et al., 2000, Chernyshov et al., 2001). The hypoestrogenic hormone status in ovarian failure patients could be responsible for the elevated numbers of activated blood T cells. It has been demonstrated that the estrogen substitution lowered the number of activated peripheral $\mathrm{T}$ cells in ovarian failure patients, although not to completely normal levels (Hoek et al 1995). Despite the fact that the data on the numbers of $\mathrm{T}$ cells vary between the reported studies, a consistent pattern of an increased number of activated (MHC II+ or IL-2R+) T cells have been demonstrated in the majority of the studies (Hoek et al., 1997). Elevation in the number of peripheral blood B cells has been reported in patients with ovarian failure (Ho et al., 1988), and in ovarian failure patients during initial period of disease (Chernyshov et al., 2001), and in patients with primary ovarian insufficiency (van Kasteren et al., 2000), and in murine autoimmune ovarian failure (Ivanova et al., 1984), and relationship of the raised numbers of $B$ cells to the presence of various autoantibodies has been also demonstrated (Ho et al., 1988). The elevated numbers of peripheral blood B cells is thought to be a sign of activation of the humoral immune system, which is crucial for autoantibody production. This can be very important because estrogen substitution in 
patients with ovarian failure did not lower the elevated number of peripheral B cells (Hoek et al., 1995). Similar immunological profile has been shown in patients with POI and in patients with POF (van Kasteren et al., 2000), suggesting that POI is a light form of POF. It has been found a decrease in NK cells and in percentage of T-suppressor cells with a rise in T-helper/T-suppressor cell ratio, as well as an increase in B-cells and HLA-DR+ T cells. The question remains whether these changes are the cause or the consequence of the ovarian failure. Autoimmune damage of the ovary could be the primary cause of POF, whereas in natural menopause autoimmunity is a result of hormone dysfunction (Chernyshov et al., 2001).

The variations of cellular immunity function and its relationship with AOA (Huang et al., 1996) and with anti-granulosa cells autoantibodies (Vangelov et al., 2009) have been investigated in patients with ovarian failure. The patients with ovarian failure have increased AOA, CD4+ T-cells and CD4+/CD8+ ratio. It has been shown also, that AOA positive rate in POF patients is associated with higher CD4+/CD8+ ratio (Huang et al., 1996).

In our study, we used our propriate granulosa cell autoantibody ELISA detection assay, and commercially available TNF- $\alpha$ and IFN- $\gamma$ ELISA kits (eBioscience, USA) to estimate the abundance of granulosa cell autoantibodies, and the concentrations of TNF- $\alpha$ and IFN- $\gamma$ in FFls, as well as DNA-DAPI staining for the assessment of granulosa cells apoptotic index in ovarian failure patients. The obtained results reveled several findings: 1) significantly higher levels of IFN- $\gamma$, TNF-a and apoptotic cells in women with positive autoantibody ELISA test, and 2) significant correlation of anti- granulosa autoantibodies, and apoptotic index, as well as significant correlation of IFN- $\gamma$ with TNF- $\alpha$ and apoptotic index. Moreover, we have reported (Vangelov et al., 2008, 2009), that cellular immunity (TNF- $\alpha$, IFN- $\gamma$ ) and humoral immunity (anti-granulosa cell autoantibodies) to granulosa autoantigens can be concurrently produced in patients with ovarian failure, and we suggested that pathogenesis of ovarian failure may be associated with immune factors and apoptosis of granulosa cells. In this scenario the programmed cell dead (apoptosis) of granulosa cells could be very important player. The ovulatory process represents the classical sequence of an acute sterile inflammation under surveillance of innate immune function (Medzhitov, 2010, Rock et al 2010). The cell damage is associated with the release of danger signals-alarmins (Bianchi 2007). In the preovulatory follicle main source of danger signals are damaged granulosa cells (Spanel-Borowski 2011) and the danger signals could be recognized by CK+(cytokeratin-positive) granulosa cells via TLR-4 or other pattern-recognition receptors (PRRs) (Serke et al., 2009, 2010). The ovarian innate immune function will be activated to orchestrate the ovulatory process (Spanel-Borowski, 2011). CK+ cells are assumed to switch off the CK genes in the corpus luteum (CL) stage of secretion and regression to become granulosa-like cells. The granulosa-like cells are thought to be mature DC in the CL (SpanelBorowski, 2011). However, the low $\mathrm{T}$ cell number in the preovulatory follicle wall is signature for a limited interaction with the adaptive immunity. A disturbed conversation between innate and adaptive immunity is reflected by altered T cell profiles in the FFls of patients with idiopathic infertility and in ovaries with POF due to autoimmune damage (Vujovic 2009, Spanel-Borowski 2011). Because DCs process antigens and train naive T cells to become helper and suppressor cells (Banchereau \& Steinman, 1998, Turvey \& Broide, 2010), DCs are players between innate and adaptive immunity. The pathway of innate immunity is well balanced to achieve the quick recovery of tissue integrity, but an 
unbalanced action can cause chronic tissue injury and autoimmune diseases. In this aspect, we have reported the relationship between the level of apoptotic granulosa cells and the level of anti- granulosa cell autoantibodies in studied patient group with ovarian failure (Vangelov et al., 2009). Moreover, the biomolecules are susceptible to glycosylation, glycation, phosphorylation and oxidation. Oxidative stress is the major event causing structural modification of proteins with consequent appearance of neo-epitopes (Buttari et al., 2005). The role for oxidative stress in promoting the autoimmune responses have been reviewed (Kannan 2006). Autoimmune responses may be directed against self-structures altered by high-affinity ligand binding or by chemical damage due to environmental events, such as oxidative stress. Several systems that generate reactive oxygen species catalyze a variety of oxidative damage to nucleic acids, lipids, and proteins. In physiological conditions oxidative stress is well compensated, but when there is an overproduction of reactive oxygen species or a deficiency of antioxidant enzyme activity, a biological damage may occur (Puddu et al., 2009). Oxidative stress and inflammation may determine the modification of self-structures also favoring the formation of Advanced glycation end products (AGEs). Chronic oxidative stress causes an accumulation of AGFs products (Ramasamy et al., 2009). The generation of AFGs products and augmentation of proinflammatory mechanisms provide a potent feedback loop for sustained oxidant stress, ongoing the generation of AFGs products. Therefore, self-molecules modified by oxidative events can become targets of autoimmune reactions, thus sustaining the inflammatory responses. In another hand, the disturbed apoptosis execution and clearance can potentially render apoptotic cells as a source of autoantigens normally sequestered in the intracellular environment. Structural changes occurring during cell death may influence the immunogenicity of clustered self-antigens at the surface of apoptotic body (Navratil et al., 2005). In this scenario, high concentrations of self-antigens are packaged during generation of apoptotic cells; the packages also may contain altered fragments of self-antigens that have not been encountered previously by the immune system; under normal circumstances, apoptotic cells are cleared rapidly by macrophages and DCs; therefore, the apoptosis-altered self-antigens are either ignored by the immune system or tolerance to those antigens is maintained. Clearance is achieved through complex mechanisms that enable macrophages and DCs to recognize apoptotic cells as nonthreatening "self" particles, but defects in this process that cause a delay in clearance could change the appearance of apoptotic cells and cause them to be recognized as "foreign invaders," thereby stimulating an inflammatory response that, in turn, activates an immune response to self-antigens (Navratil et al., 2005).

The ovary is an extremely dynamic organ in which excessive or defective follicles are rapidly and effectively eliminated throughout reproductive life. Greater than $99 \%$ of follicles disappear, due to apoptosis of granulosa cells. The balance between signals for cell death and survival determines the destiny of the follicles. The potential use of scores for apoptosis in granulosa cells and characteristics of FFls have been discussed more recently as prognostic markers for predicting the outcome of assisted reproduction (Lefèvre et al., 2011). Follicular fluid and surrounding tissue contains various lymphocytes that synthesize different cytokines. The other sources of cytokines are ovarian somatic cells. We studed the impact of proinflamatory cytokines TNF- $\alpha$ and IFN- $\gamma$ concentration in FFls, and apoptotic index of granulosa cells on the results of $\mathrm{COH} / \mathrm{IVF}$ in women with ovarian failure (Vangelov et al., 2009). The obtained results in this study clearly showed that the elevated levels of TNF- $\alpha$ and IFN- $\gamma$ were directly related with increased incidences of apoptotic 
granulosa cells and altogether were associated with poor $\mathrm{COH} / \mathrm{IVF}$ outcome. Moreover, earlier Cianci et al., 1996 reported association of elevated concentration of TNF-a with reduced fertilization rate in women with immunological infertility and concluded, that the elevated TNF- $\alpha$ concentration in the human follicle may negatively influence both ovulation and fertilization related events.

\section{Intra ovarian regulators of survival and apoptosis in preovulatory follicle}

\subsection{Apoptosis of granulosa luteinized cells (GLCs) and cumulus cells (CCs) - predictive marker for results of $\mathrm{COH} /$ IVF outcome in infertile women}

The oocyte-cumulus-granulosa cells unit comprises an intimate relation between somatic cell syncytium in conjunction with the oocyte involving gap junctions and complex of hormonal and peptide factors. Granulosa cells and cumulus cells play a critical role in oocyte maturation and fertilization by releasing and mediating signals to oocytes. On the other hand the oocyte also influences granulosa cells steroidogenesis, proliferation and Hyaluronic acid synthesis by CCs. Each participant in this unit can disturb signaling and regulation of apoptotic process. Apoptosis is self-destruction under physiological control and is closely involved with most of the reproductive processes, including follicular atresia. Apoptosis can be used to estimate a function of ovarian reserve in women undergoing IVF (Seifer et al., 1996). Many studies have provided evidence that poor oocyte, low IVF outcome and embryo quality can be associated with apoptosis. The incidence of apoptotic bodies has been used as a morphological marker for physiological cell renewal (Tilly et al., 1991) and the presence of apoptosis in human GLCs and CCs in COHS during IVF treatment, has been used as a very sensitive indicator for evaluation of oocyte quality and the IVF outcome (Nakahara et al., 1997; Suh et al., 2002).

The isolated GLCs (Vangelov et al., 2005) were fixed with formaldehyde. The GLCs suspensions were dropped on poly L-Lysine treated slides. CCs were isolated from individual cumulus-oocyte complexes (COCs) of the same patients, and were divided according to the oocyte maturation (immature - G.V. or MI or mature - MII oocytes). The cumulus masses were dispersed with 150 IU Hyaluronidase and after that were fixed and processed as GLCs.

Apoptosis of GLCs and CCs was assayed using DNA-DAPI staining (Dineva et al., 2006) that allows the observation of morphological changes of nuclear chromatin in GLCs and CCs. Morphological characteristics of apoptosis such as chromatin condensation and/or nuclear fragmentation were identified and counted in randomly selected fields among 8001000 cells and the percentage of apoptotic cells was calculated. The significant negative correlations between the rate of apoptosis in GLCs and both - the number of preovulatory follicles, and the number of retrieved and fertilized oocytes from patients in stimulated cycles was found.

The most convenient evaluation system for oocyte quality is based on oocyte morphology and status of oocytes-cumulus complexes. Cumulus cells surround and intercommunicate with oocytes during follicular development and after ovulation, suggesting that the incidence of apoptosis in cumulus cells could influence oocyte quality (Lee et al., 2001). In our study we found that the rate of apoptosis in GLCs is higher compared to CCs cells from 
the same patient. The higher rate of apoptosis in CCs from follicles with immature oocytes than from those with mature showed that the level of CCs apoptosis is directly related to the maturation of oocytes and support the data of Host et al., 2000.

The obtained results showed that the incidence of apoptosis in GLCs as well as in CCs could be a predictive marker for IVF outcome.

\subsection{Role of Atrial Natriuretic Peptide (ANP) in the ovarian immunoendorine function}

\subsubsection{GLCs are the main local source of ANP in the preovulatory human follicle}

Many endocrine, paracrine and autocrine factors (gonadotrophic and steroid hormones, peptide hormones, cytokines, highly- reactive free radicals) play an important role in the regulation of GLCs proliferation, differentiation and death.

The expression of natriuretic peptides (NPs) and its receptors (NPRs) has been demonstrated in the mammalian ovary (Gutkowska et al., 1993; Russinova et al., 2001).

The presence of ANP was demonstrated in the follicular fluid (Kim et al., 1987); granulosa cells (Ivanova et al., 2003) and luteal cells (Vollmar et al., 1988). ANP plays an important role in the regulation of different aspects of ovarian physiology, such as oocyte meiosis, cumulus cells expansion, spontaneous oocyte maturation, ovarian steroidogenesis and follicular atresia (Samson WK et al., 1988, Tornel et al., 1990; Gutkowska et al., 1999; Zhang et al., 2005).

The indirect immunofluorescence technique (IIF) was used to investigate the localization patterns of ANP on GLCs isolated from women undergoing IVF. The isolated GLCs were fixed on the protocols mentioned above. The GLCs suspensions were dropped on poly LLysine treated slides. The cells were permeabilized with Triton X-100 for $5 \mathrm{~min}$ and after washing the cells were incubated with cocktail of monoclonal antibodies (Mabs) against recombinant human ANP (Mabs: 6C3, 6F11, 5D3 supernatants), obtained and characterized at the Department of Molecular Immunology (Institute of Biology and Immunology of reproduction, Sofia, Bulgaria), diluted 1:1 in PBS/BSA, overnight, followed by washing with PBS-Tween 20 and then incubated with secondary antibody (Sw/am IgG labeled with FITC, Sevac, Czech Republic), diluted 1:20, for 1h. After washing in PBS-Tween 20, slides were mounted with Mowiol (Sigma $\left.{ }^{\circledR}\right)$. The expression and localization of ANP were examined using fluorescence microscope (Leiz Labor-Lux, Zeiss). The immunofluorescent expression level of ANP was scored as the intensity of specific immunofluorescence and the number of positive cells from $(+)$ to $(+++)$ as follows: $(+++)$ - intensive immunoreactive ANP expression in prevailing cells population; $(++)$ - intensive immunoreactive ANP expression in most of cells observed; $(+)$ - intensive expression of immunoreactive ANP in a minority of cells observed.

ANP expression was observed as membrane, submembrane and particular granular cytoplasm localized staining. The mature ANP is generated by proteolytic processing in two steps: generation of pro-ANP (stored in the cytoplasmic granules) from immature pre-pro ANP (Bloch et al., 1985), followed by proteolytic maturation of pro-ANP to mature bioactive ANP (Schwartz et al., 1984). The bioactive ANP gets into extracellular space and in this manner ANP acts as autocrine and/or paracrine factor that modulates different aspects of GLCs functions. We consider that the different patterns of ANP expression in GLCs 
represent localization of ANP during the different stages of posttranslational processing and/or export of ANP from GLCs.

The women included in this study were divided into two groups: women with high level of ANP expression and women with low level of ANP expression in GLCs.

For us the question of great interest was, whether the GLCs are the principal source of ANP in the human preovulatory follicle? For this reason, we measured the ANP concentrations in FFl obtained from the same woman that donated the GLCs specimens followed by an analysis of relationship between the follicular ANP concentration and the expression levels of immunoreactive ANP in GLCs. The concentration of ANP was measured in FFls, obtained from the same woman using a proANP (1-98) kit, with levels of immunoreactive ANP in GLCs found positively correlating to the corresponding FFls ANP concentrations. The concentration of ANP in the FFls of women with high level of immunoreactive ANP expression in GLCs was found to be significantly higher, compared to the women with low level of ANP expression in GLCs.

Our earlier study showed that, in in vitro luteinized porcine granulosa cells (isolated from prepubertal porcine ovaries) supplemented with FSH and luteinizing hormone (LH), the expression of immunoreactive ANP was increased and was highest among the FSH and LH treated GLCs (Dineva et al., 2007).

The established positive relationship between the levels of ANP in FFls and its immunoreactive expression on GLCs together with findings of in vitro experiment show that the GLCs are the main local source of ANP in the preovulatory human follicle.

\subsection{ANP is survival factor for GLCs in preovulatory follicle}

Diverse effects of NPs are mediated by the activation of membrane bound receptors with a particulate guanylate cyclase (GC) activity to generate Cyclic Guanosine Monophosphate (cGMP). The physiological activities of ANP are mediated by a specific plasma membrane receptor, guanylate cyclase-type receptor GC-A (Chang et al., 1989). Recent studies have shown that components of cGMP signaling pathways are expressed in the ovary and that cGMP can alter granulosa cell function (La Polt et al., 2003). The cGMP/PKG signaling is a target for the prevention of mitochondrial dysfunction-mediated cell death (Chun SY et al. 1996, Takuma et al. 2001).

The survival role of ANP for GLCs, was studied in cultured human GLCs treated with 2BucGMP (analog of cGMP, Sigma) and with human recombinant ANP (hrANP, Sigma). The higher level of ANP production (after 2Bu-cGMP treatment) and the supplementation of cultured GLCs with hrANP were associated with significant suppression of Caspase-3 activity, that is to say, with the inhibition of apoptosis in GLCs, compared to control cells. For Caspase-3 activity assay, the cultured cells were lysed and the soluble fraction of the cell lysate was assayed using specific substrate (Dineva et al., 2007)

\subsection{Role of ANP for folliculogenesis and results of COH/IVF}

ANP can affect oocyte maturation via cGMP signaling pathways, and suppress spontaneous oocyte maturation (Zhang et al., 2005) and in this manner ANP may be the factor which determines the development of fertilizable oocytes. We analyzed the relationship between 
the concentrations of ANP in FFls obtained from women undergoing IVF with the number of punctured follicles and the number of retrieved oocytes (results of $\mathrm{COH}$ ), as well as with the number of fertilized oocytes (results of IVF). The significant positive correlation of follicular ANP with the number of punctured follicles, the number of retrieved oocytes and with the number of fertilized oocytes were documented. Data analysis showed that the level of expression of ANP in the GLCs and its concentration in FFls are potential prognostic markers for $\mathrm{COH} / \mathrm{IVF}$ outcome.

The higher levels of ANP were associated with "good" folliculogenesis (a high number of punctured follicles and a high number of oocytes retrieved) and with the development of fertilizable oocytes (high number of fertilized oocytes), as a consequence of its direct actions on somatic cells and on oocytes and of its role as a survival factor in the preovulatory human follicle.

\subsection{Immunomodulatory role of ANP in preovulatory follicle}

In the ovary, many cytokines play an important role in regulation of ovarian steroidogenesis, corpus luteum formation and function, and ovulation (Adashi, 1990). Atrial natriuretic peptide expression from different components of immune system had demonstrated (Kiemer et al., 2000). Macrophages are capable to synthesize ANP and its active state are associated with elevate level of ANP production (Vollmar \& Schulz, 1995). Many data showed, that resident ovarian white blood cells are in situ immunomodulator of processes realize in the ovarian follicle, specially ovulation, an inflammatory-like processes, in which immune cells, including macrophages, play very important role (Bukulmez \& Arici, 2000, Richards et al., 2002 ).

The immunomodulatory effect of ANP was studied on in vitro model of peripheral blood cells. Whole human peripheral blood samples, obtained from at least three healthy women, were used for in vitro culture preparation. The cytokine production in all blood samples was stimulated by lipopolysacharide (LPS). The rest cells were treated with human recombinant ANP in different concentration from $10^{-6}$ to $10^{-8} \mathrm{M}$. The part of cells was treated with $10^{-12} \mathrm{M}$ ANP, concentration of ANP measured in FFls obtained of women undergoing IVF procedure.

The concentrations of proinflammatory cytokines, TNF- $\alpha$ and IFN- $\gamma$ in plasma samples, were determined by sandwich-based TNF- $\alpha$ and IFN- $\gamma$ kits, respectively (E-Bioscience).

The obtained results showed that ANP dose dependently inhibits synthesis of TNF- $\alpha$ and

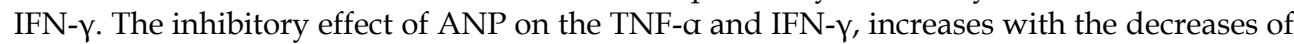
its concentration and is most pronounced at concentrations of ANP $\left(10^{-8} \mathrm{M}\right.$ and $\left.10^{-12} \mathrm{M}\right)$, established in FFls.

The level of transcription and synthesis of TNF-a is controlled by two factors: Activation protein 1 (AP-1) and Nuclear factor kappa B (NF-kB) (Rhoades et al.,1992), and ANP inhibits their activation by cGMP mediated pathways (Tsukagoshi et al., 2001; Kiemer \& Vollmar, 2001). Furthermore, NF-kB and Nuclear Factor of Activated $\mathrm{T}$ cells (NFAT) control transcription of the gene for IFN- $\gamma$ and hence the synthesis IFN- $\gamma$ (Sica et al., 1997). The ANP inhibits the activation of NF-kB in cells and tissues which is important for the release of many inflammatory molecules and inflammatory response (Zhang et al., 2008). These data 
and obtained results by us showed that ANP is an important intra ovarian regulator of inflammatory response and is a potential modulator of immune environment within preovulatory follicle.

\subsection{Role of antioxidant enzymes in ovarian function}

\subsubsection{Survival role of Superoxide dismutase (SOD) and Catalase (CAT) for GLCs}

Physiological processes in the ovary have a dynamic character and are accompanied with the change in the intensity of cellular metabolism and cellular oxygen consumption, resulting in the generation of reactive oxygen compounds (ROS, reactive oxygen species). The protection from ROS is realized by both: low molecular weight natural antioxidants (antioxidant vitamins and polyphenols) and antioxidant enzyme systems. The enzymatic antioxidant defense include: superoxide dismutase (SOD) catalase (CAT) and glutathione peroxidases (GPRXs). These three enzymes act in a cooperative or synergistic way to ensure a global cell protection. To cope with ROS, cells express an array of antioxidant enzymes, including the superoxide dismutases (SOD) (e.g. cytosolic $\mathrm{Cu} / \mathrm{Zn}$ - SOD, mitochondrial MnSOD and extracellular $(\mathrm{Cu} / \mathrm{Zn})$ - EC- SOD) which convert superoxide anions to hydrogen peroxide, that is then transformed to water by catalase (CAT) and by glutathione Speroxidase. When the balance between physiological ROS production and the antioxidant defences becomes unbalanced, this disequilibrium may drive the cell to cell death (Orrenius et al., 2007).

Biological reactions that reduce the "harmful" levels of free radicals are of prime importance in reproductive systems in maintaining the quality of gametes and support reproduction.

We used a $48 \mathrm{~h}$ in vitro model of human GLCs, to investigate how the supplementation with various concentrations of $\mathrm{Cu}, \mathrm{Zn}-\mathrm{SOD}$ or the treatment with various concentrations of $\mathrm{Cu}$ chelating agent sodium diethyldithiocarbamate (DDC) influences GLCs total SOD activity and the GLCs viability (Caspase-3 activity) and how these parameters are interrelated.

The isolated GLCs from at least three women were cultured in 96- well plates (Linbro® Flow Labs, Virginia, USA), (50 $\mathrm{\mu l} /$ well). After $24 \mathrm{~h}$ culture period the cells were supplemented with 10, 100, $200 \mathrm{U} / \mathrm{ml}$ SOD1 (Cu, Zn-SOD, Inst. Microbiology, Bulg.Acad.Sci.) The purified $\mathrm{Cu}, \mathrm{Zn}$-SOD enzyme is a water-soluble homodimeric glycoprotein with a molecular mass of approximately $31700 \mathrm{Da}$ and was isolated from Humicola lutea 103 (Krumova et al., 2007). The rest of cells without control were treated with 10, $100 \mu \mathrm{M}$ DDC (Sigma). The Caspase-3 activity was measured as mentioned above. The total SOD activity in GLCs at the end of the culture period (48 h), was measured according the method of Beaushap \& Fridovich (1971).

Based on measured GLCs total SOD activity, anti-oxidative effect of low dose DDC $(10 \mu \mathrm{M})$ and pro oxidative effect of high dose DDC $(100 \mu \mathrm{M})$ were documented: significantly higher GLCs total SOD activity (10 $\mu \mathrm{M}$ DDC) and significantly lower GLCs total SOD activity (100 $\mu \mathrm{M}$ DDC) was measured, respectively, compared to the control cells.

The highest activity of Caspase-3, measured after the treatment with $100 \mu \mathrm{M}$ DDC was followed by lowest total GLCs SOD activity, showing the direct role of $\mathrm{Cu}, \mathrm{Zn}$ - SOD in the prevention of human GLCs from apoptosis. A possible cooperation of SOD and cytochrome $\mathrm{C}$ in mitochondria-dependent apoptosis has been described by $\mathrm{Li}$ et al 2006. The simultaneous release of SOD with cytochrome $\mathrm{C}$ has been shown to regulates mitochondria- 
dependent apoptosis increasing the susceptibility of mitochondria to oxidative stresses (Li et al 2009), whereas the active enzyme has been reported to be implicated in protecting vital mitochondria (Iñarrea et al., 2007). In this study for first time, we demonstrated that the supplementation with $\mathrm{Cu}, \mathrm{Zn}-\mathrm{SOD}(200 \mathrm{U} / \mathrm{ml})$ was closely involved in anti-apoptotic mechanisms and maintains the human GLCs viability in vitro, by the suppression of Caspase-3 activity.

\subsubsection{Relationship between activity of antioxidant enzymes SOD and CAT in GLCs with COH / IVF outcome}

Oocytes and granulosa cells in all follicular stages are endowed with the major antioxidant and detoxifying enzymes (e.g. SOD and CAT) (Suzuki et al., 1999; Mouatassim et al., 1999). SOD activity and CAT activity have been demonstrated in human FFls (Carbone et al., 2003; Pasqualotto et al. 2009; Bausenwein et al., 2010). The expression of SOD and of CAT at mRNA and protein level have been studied in human follicular somatic cells, such as GLCs and CCs in relation to female reproductive aging and successful outcome of assisted reproductive technologies, respectively (Tatone et al., 2006; Matos et al., 2009). The aim of our study was to investigate the relationship among the activity of superoxide dismutase (SOD) and catalase (CAT) in GLCs and apoptosis of these cells with the results of COH/ IVF in infertile women.

For detection of apoptosis in GLCs the method of DAPI-DNA staining was used. The activity of intracellular SOD and CAT of GLCs were measured using the Beaushap \& Fridovich; Beers \& Sizer methods, respectively (Beers \& Sizer, 1952; Beaushap \& Fridovich, 1971).

We studied the relationship between the activity of SOD and CAT in GLCs with the level of apoptosis (\% apoptotic hGLCs) and with the parameters of $\mathrm{COH}$ and IVF. The balance between the ROS production, cellular antioxidant defenses, activation of stress-related signaling pathways, and the production of various gene products, will determine whether a cell exposed to an increase in ROS will be destined for survival or death (Kregel \& Zhang, 2007). The SOD and CAT play a central role in the antioxidative defense in the ovary and they act in tandem to neutralize the supra physiologic levels of ROS.

Within the studied patient's groups we found that the "health" status of human GLCs (low level of apoptosis) is associated positively with both, SOD and CAT activity in GLCs obtained from the same woman.

Oxidative stress in granulosa cells was suggested to decrease both fertilization rate and quality of embryos in IVF cycles (Seino et al., 2002). Elevated level and high activity of SOD are associated with better quality of oocyte, and good embryo development, influenced, probably, by the oxidant/antioxidant (du Plessis et al., 2008). Our results demonstrated that the better outcome in the COH/IVF cycles, such as higher numbers of retrieved and fertilized oocytes are related to higher intra cellular SOD activity in GLCs. We consider that the intra cellular SOD activity in GLCs has contribution to the vital oocyte microenvironment, supported also by SOD activity in cumulus-oophorus cells (Matos et al., 2009) as well as by SOD and CAT activity of FFls (Kably Ambe et al., 2005; Pasqualotto et al., 2009), and that intra cellular SOD activity could be a potential biomarker for ART success. 


\section{Gene expression in cumulus cells as biomarker for oocyte competence}

Pregnancy and birth rates in assisted reproductive technology (ART), following in vitro fertilization (IVF) are unique events but unfortunately 2 out of 3 IVF cycles fail to result in pregnancy. Due to the subjective morphological parameters in selection of healthy embryos used in IVF and ICSI programmes, 8 out of 10 transferred embryos fail to implant (Kovalevsky, G. \& Patrizio, P., 2005). Consequently, selecting oocytes with normal developmental competence and embryos with the highest implantation potential is of great importance in assisted reproductive technology.

\subsection{Cumulus cells as targets of biomarkers}

Ovarian follicle development and maturation are complex processes, involving both the oocyte and its surrounding transcriptionally distinct CCs and GLCs (Eppig et al., 2001). Mammalian oocyte growth and development is critically dependent on the functional twoway communication axis that exists between the germ cell and its immediate companions the ovarian cumulus cells. This communication is in form of direct gap-junction communications and paracrine signaling mediated via soluble oocyte-secreted factors (McNatty et al., 2004). It is well recognized now, that the oocytes also promote cumulus and granulosa cell proliferation, differentiation and apoptosis, suggesting that the health and function of the granulosa and cumulus cells being may be reflective of the health status of the enclosed oocyte (Eppig et al., 2001). Since the CCs and GLCs transcriptomic profiles are influenced of the bidirectional oocyte-somatic cells communication, and thus these profiles could serve as an approximate reflection of the oocyte developmental competence. Perturbations in the oocyte functionality both genetic and functional would result in an altered oocyte-cumulus signaling and thus an altered cumulus transcriptome. In this way, the study of the CCs transcriptomic profile offers the opportunity, by a non-invasive method, to predict oocyte and eventually embryo competence (Assou et al., 2010).

Derived from this paradigm, we believe that after clinical validation a small subset of particular genes would render relatively cheap and non-invasive test for screening of good competence oocytes in all cases when ART procedures are involved, but pre implantation genetic diagnostic (PGD) of succeeding embryo might be not available or should be avoided.

We have recently investigated several gene transcript products as part of larger set of cumulus-derived oocyte competence-predicting genes as a pilot evaluation study and prove of concept, namely: lysyl oxidase (LOX), basigin (BSG), phosphoglycerate kinase 1 (PGK1) and nuclear factor kappa-light-chain-enhancer of activated B cells (NF-kB) (Todorova et al., 2011a, 2011b). We have also studied known protein transcriptional factors that might also impact the oocyte competence in case of altered abundance, perturbing the oocyte development, maturation or fertilization, and thus the oocyte fertility competence.

\subsection{The study concept of the transcript biomarkers}

Specimens from multiple oocyte-neighboring cumulus cells were isolated from three investigated patients' groups: women with reproductive problems, participating in ICSI procedures with primary sterility; women with reproductive problems, participating in ICSI procedures with secondary sterility; women with so called "male factor sterility" (where 
reproductive failure is result in male infertility) and women who participated in "healthy donors" in vitro programs. All three groups of women were subject to hormonal stimulation short or long protocols, involving at least FSH and Progesterone.

A quantitative reverse transcriptase real-time PCR approach was applied to estimate the differential gene expression levels of the LOX and BSG gene transcripts, normalized to the house keeping gene PGK1, in the cumulus cells surrounding acquired oocytes from ICSItargeted primary and secondary sterility IVF patients and healthy fertile donors.

After separation of the CCs from each acquired oocyte, the specimens were individually collected and they were subject to consecutive lysis, mRNA extraction, reverse transcriptase gene specific cDNA synthesis and PCR amplification. For this approach we utilized the one step Fastlane Cell RT-qPCR Kit (Qiagen, USA). The assays were run on a qPCR Cycler (Agilent Technologies MX3005P, Stratagene, USA) using the exact thermal protocol supplied by the manufacturer. The primers were produced by Biomers, Germany.

The data obtained by the qPCR reaction were subsequently subject to analysis by Stratagene MxPro software and represented as gene transcript fold change, where donor specimens were set as 0 fold change. The subsequent statistical analyses included non-parametric Kruskal-Wallis non-parametric ANOVA on the normalized expression levels of lox and $b s g$, expressed as fold change compared to donor expression.

We used $p g k 1$ as housekeeping normalizing gene since it is a transferase enzyme that in humans is involved in main biochemical pathway - the glycolysis, transferring a phosphate group from 1,3-biphosphoglycerate to ADP, with formation of ATP and 3-Phosphoglycerate (Singer-Sam et al., 1984). It has been also considered as suitable housekeeping gene for the cumulus cells as it is found in all living organisms and its sequence has been highly conserved throughout evolution (Kumar et al., 1999).

\subsection{The putative markers}

Lysyl oxidase also known as protein-lysine 6-oxidase is a protein that, in humans, is encoded by the LOX gene. Its upregulation by tumor cells may promote metastasis of the existing tumor, causing it to become malignant and cancerous (Hämäläinen et al., 1991). This enzyme oxidized peptidyl lysine to pepttidyl aldehyde residues within collagen and elastin, initiating formation of the covalent cross-linkages that insolubilize these extracellular proteins (Li et al., 1997). This function of LOX made it implicated so far in both ovary extracellular matrix synthesis and to some extent in policistic ovary cystogenesis in rat models as well (Papachroni et al., 2010). LOX was found to be under endocrine, paracrine, and autocrine control, with FSH being major coordinator of its response to these stimuli (Harlow et al., 2003).

Jiang et al., 2010 investigated whole genome gene expression profiling of mural granulosa cells and the authors demonstrated that mural granulosa cells isolated from follicles containing oocytes with normal developmental competence are distinct from those with oocytes exhibiting poor developmental competence. These authors established that there were genes which profiles are different in two investigated groups. They reported lox expression to be 2.8-fold higher in mural granulosa cells isolated from follicles containing oocytes which exhibit normal developmental competence when compared with poor ones. These results were validated by real-time PCR (Jiang et al., 2010). 
Our data are in controversy with the above findings observing quite the opposite phenomenon - LOX mRNA expression estimated with comparative quantitative real-time PCR (2- $\Delta \Delta \mathrm{Ct}$ method) was almost 4.32-fold higher (mean value) in infertile women with primary sterility and reproductive failure, compared to fertile donors. LOX mRNA is upregulated in women with primary or secondary sterility. The difference observed in women with secondary sterility was also increased in favor of the donors - 3.85. (Todorova et al., 2011a, 2011b). We believe that one possible explanation would be that in the above mentioned study (Jiang et al., 2010) immature rats were subject of an anti-eCG treatment with subsequent induction of apoptosis in the granulosa cells, and folliclar atresia, an effect that they report as antibody dose-dependent. In our study design (Todorova et al., 2011a, 2011b) human subjects were studied and even though they could have varying degree of hormone levels, those are both medication stimulated, and followed as feedback, and no patient participates in ART program unless normal (target range) hormone levels are achieved, and latter normal oocyte morphology is prerequisite for subsequent IVF/ICSI procedure. The observed LOX levels are most likely related to the stimulation protocol that induced follicle maturation (GnRH or FSH) and later on - oocyte maturation (hCG) and ovulation. FSH and hCG (eCG) were found to downregulate LOX gene expression. Therefore it should be expected that in the cumulus cells of fertile women and healthy donors rather decreased lox mRNA transcript levels would be observed. Parallel to that, the lox gene expression is able to suppress oocyte maturation in experimental model systems, suppressing both RAS and Progesterone induction (Di Donato et al., 1997). Thus some subtle differences between donor's and IVF/ICSI failure oocytes exist, that are neither directly reflected by the woman hormonal levels, nor by the oocyte parameters alone. Besides in Jiang et al., 2010 study mural granulosa were analyzed, rather than human cumulus cells.

It has to be noted that there is growing evidence for functional difference in transcriptomes expressed in the oocyte adjacent cumulus cells and the granulosa cells located further on. Although morphologically they may seem the same, the existence of paracrine signaling axis between oocyte and adjacent somatic cells creates a signaling molecules concentration gradient that renders different responses and hence distinct expression profiles in the somatic cells across the oocyte follicle. Whether there are more stable and long lasting differences remains yet to be established.

A more in depth analysis of oocyte physiology reveals that LOX has been shown to participate in very important processes connected with the cell differentiation of granulosa cells (Jiang et al., 2010). TGF- $\beta 1$ and GDF9 increase lox mRNA expression in rat granulosa cells (Kendall et al., 2003). The GDF9-induced preantral follicular growth in vitro involves increased mural granulosa cell lox mRNA expression (Assou et al., 2010), and similarly the investigations on rat granulosa cells showed that lox transcripts were significantly suppressed 48h after eCG injection compared with untreated controls (Jiang et al., 2010). Harlow et al. demonstrated that while in primary and especially in preantral follicle GDF-9 increases extremely LOX expression, in antral follicle in which the levels of FHS-receptors are induced, FSH dose-dependently decreases the LOX levels, while GDF-9 induction effect is diminished. In this context the lox mRNA and protein expression levels should be expected to be decreased, rather than increased (Harlow et al., 2003). This could serve as legitimate explanation, why in women with infertility the levels of lox mRNA are actually increased, with highest levels in those who are having primary sterility. 
Basigin is a member of the immunoglobulin superfamily that is also known as EMMPRIN, short for extracellular matrix metalloproteinase inducer (Miyauchi et al., 1992). BSG has already been shown to be expressed in the ovary and play key roles in fertility. It appears to be critical for both ovulation and implantation. BSG plays fundamental roles in various immunologic phenomena, differentiation, development and intercellular recognition. Knock-out of BSG in mice results in infertility in both sexes. It was demonstrated that bsg gene disruption produces failure of female reproductive processes affecting both implantation and fertilization (Kuno et al., 1998). BSG mRNA expression in cumulus cells and basolateral localization of the BSG protein in the endometrial epithelium further support the importance of BSG in these processes (Smedts, A., \& Curry, T. (2005). Our data showed an increase of approximately 6.5 fold for $B S G$ in primary sterility women compared to the fertile donors (Todorova et al., 2011a, 2011b). The difference observed in women with secondary sterility was also increased in favor of the donors - 2.5 for BSG. Correlation statistical analysis applied to the fold-change expression rates of $L O X$ vs. BSG using the data acquired for every single specimen of cumulus cells suggested although low power, but positive correlation between the lox and bsg gene expression levels. The Coefficient of determination $\left(\mathrm{r}^{2}\right)$ as measure of the significance of the correlation between LOX and BSG was 0.5 .

\subsection{The study concept of the transcriptional factor NFKB involvement}

Protein lysates from the same oocyte neighboring cumulus cells were subject to SDS-PAGE and subsequent Western blotting for specific antibody-mediated immunological detection of activated NFKB transcription factor. Lysates from cumulus cells were run under reducing conditions in a $12 \%$ SDS-PAGE gel. The separated proteins were transferred to a polyvinylidene fluoride membrane (Sigma, St. Louis, MO, USA). The membranes were blocked and then incubated with anti-NFKB antibody (R\&D, USA). The membranes were washed and incubated with anti-mouse ALEXA 488 antibody conjugated. The Western blots were visualized by fluorescent scanner - Ethan DIGE (General Electric, USA), using membrane scanning protocol and appropriate for ALEXA 488 exposure times of the Cy2 preset channel in the acquisition software.

NFKB is a protein complex that controls the transcription of DNA. NF-KB is found in almost all animal cell types and is involved in cellular responses to stimuli such as stress, cytokines, free radicals, ultraviolet irradiation, oxidized LDL, and bacterial or viral antigens. NF-kB plays a key role in regulating the immune response to infection (Gilmore et al., 2006). Resent study has shown that LOX has a binding domain for NFKB making it a putative binding partner and interactor (Li, D., \& Mehta J. 2000.; Chen et al., 2006).

As a provisionary Western blot suggest, there is distinct protein level expression of NF- $\mathrm{kB}$ among the investigated groups of fertile vs infertile women. Immunoblotting with antiNFKB antibody demonstrated elevated levels of active NFKB in women with reproductive failure, while in donors this stress molecule was not nuclear translocated and detectable. The expression was higher in women with secondary sterility compared to those, (subject to ICSI,) with primary sterility (Todorova et al., 2011). It is controversial why NFkB is increased mostly in secondary sterility patients, since it is stress and inflammation related transcriptional factor, but it has to be noted, that a lot of paracrine singling is mediated by interleukins, and other factors released after NFKB nuclear translocation (Paciolla et al., 2011). 
The quality of the oocyte is largely dependent on its follicular environment. Developmental competence of the oocytes is a major determinant in the establishment of successful pregnancy in assisted reproduction. The primary criterion for oocyte selection in the human fertility clinic is the morphological characteristics of oocytes that is highly biased and does not accurately predict the quality of the oocyte (Ebner et al., 2003). Many studies reported that cumulus and granulosa cell gene expression is associated with oocyte health and development (Assou et. al., 2010).

Our studies on LOX expression profile in human cumulus cells is the first investigation ever done on human subjects. Our findings suggest that LOX, and to lesser extent BSG may prove first step and prove of concept as future screening panels incorporated markers for oocyte developmental competence. An ongoing research is currently in progress to confirm our suggestion and extend the suggested panel.

\section{Conclusion}

The study of the ovarian function in the context of both innate to adaptive immunity interaction and the role of such fundamental processes as apoptosis and oxidative stress challenge with their arising complexity and multimodality. We believe that our research will contribute to the discussed in this text long term exploration of the ovarian biology and immunology by the reproductive biology scientific community, providing us with an insight and new clues regarding the non-invasive evaluation of the biological fertility potential and future technological aids in favor of the reproductive medicine. We believe that these infertility biomarkers will prove significant capacity as fertility and oocyte competence predictors.

\section{Acknowledgements}

Project DOO2-50/2008 "Establishment of center for research on problems of the reproductive health", National Science Fund, Ministry of Education and Science

Project FP7-REGPOT-2009-1 (ReProForce) "Reinforcement of the Research Capacity of the Bulgarian Institute "Biology and Immunology of Reproduction"

\section{References}

Adashi, E. (1990). The potential relevance of cytokines to ovarian physiology; the emerging role of resident ovarian cells of the white blood cell series. Endocrine Reviews, Vol. 11, No. 3, pp. 454-64, ISSN 1945-7189

Alborzi, S., Tavazoo, F., Dehaghani, A., Ghaderi, A., Alborzi, S. \& Alborzi, M. (2009). Determination of antiovarian antibodies after laparoscopic ovarian electrocauterization in patients with polycystic ovary syndrome. Fertility and Sterility. Vol. 91, No.4, pp. 1159-1163, ISSN 1556-5653

Assou, S., Haouzi, D., Vos J. \& Hamamah, S. (2010). Human cumulus cells as biomarkers for embryo and pregnancy outcomes. Molecular Human Reproduction.Vol. 16, No 8, pp. 531-538 ISSN: 13609947 
Bakalov, V., Anasti, J., Calis, K., Vanderhoof, V., Premkumar, A., Chen, S., Furmaniak, J., Smith, B., Merino, M. \& Nelson, L. (2005) Autoimmune oophoritis as a mechanism of follicular dysfunction in women with $46, \mathrm{XX}$ spontaneous premature ovarian failure. Fertility and Sterility. Vol. 84, No. 4, pp. 958-65, ISSN 1556-5653

Banchereau, J. \& Steinman,R. (1998). Dendritic cells and the control of immunity. Nature. Vol. 392, No. 6673, pp. 245-252, ISSN 1476-4687

Barbarino-Monnier, P., Jouan, C., Dubois, M., Gobert, B., Faure, G.\& Béné, M.(2003) Antiovarian antibodies and in vitro fertilization: cause or consequence? Gynécologie Obstétrique \& Fertilite. Vol. 31, No. 9, pp. 770-773, ISSN 1297-9589

Barber, M. \& Fayrer-Hosken, R. (2000). Possible mechanisms of mammalian immunocontraception. Journal of Reproductive Immunology. Vol. 46, No. 2, pp. 10324, ISSN 0165-0378

Batova, I., Ivanova, M., Mollova, M. \& Kyurkchiev, S. (1998) Human sperm surface glycoprotein involved in sperm-"zona pellucida" interaction. International Journal of Andrology. Vol. 21, No. 3, pp. 141-153, ISSN 1365-2605

Bausenwein, J., Serke, H., Eberle K., Hirrlinger, J., Jogschies, P., Hmeidan, F., Blumenauer, V. \& Borowski, K. (2010). Elevated levels of oxidized low-density lipoprotein and of catalase activity in follicular fluid of obese women. Molecular Human Reproduction, Vol. 16, No. 2, pp. 117-124, ISSN 1460-2407

Beauchamp, C. \& Fridovich, I. (1971). Superoxide dismutase: improved assays and an assay applicable to acrylamide gels. Analytical Biochemistry. Vol. 44, No. 1, pp. 276-287, ISSN 1096-0309

Beers, R. \& Sizer I. (1952) A spectrophotometric method for measuring the breakdown of hydrogen peroxide by catalase. Journal of Biological Chemistry. Vol. 195, No. 1, pp.133-140, ISSN 1083-351X

Betterle, C., Dal Pra, C., Mantero. F. \& Zanchetta, R. (2002). Autoimmune adrenal insufficiency and autoimmune polyendocrine syndromes: autoantibodies, autoantigens, and their applicability in diagnosis and disease prediction. Endocrine Reviews. Vol. 23, No. 3, pp. 327-64. ISSN 1945-7189

Bianchi, M. (2007). DAMPs, PAMPs and alarmins: all we need to know about danger. Journal of Leukocyte Biology. Vol. 81, No. 1, pp. 1-5, ISSN 1938-3673

Bloch, K., Scott, J., Zisfein, J., Fallon, J., Margolies, M., Seidman, C., Matsueda, G., Homcy, C., Graham, R. \& Seidman, J. (1985) Biosynthesis and secretion of proatrial natriuretic factor by cultured rat cardiocytes. Science, Vol. 230, No. 4730, pp. 11681171, ISSN 1095-9203

Broer, S., Eijkemans, M., Scheffer, G., van Rooij, I., de Vet, A., Themmen, A., Laven J., de Jong F., Te Velde, E., Fauser, B. \& Broekmans, F. (2011). Anti-mullerian hormone predicts menopause: a long-term follow-up study in normoovulatory women. Journal of Clinical Endocrinology \& Metabolism. Vol. 96, No. 8, pp. 2532-2539, ISSN 1945-7197

Brozzetti, A. , Marzotti, S. , Torre, D.La , Bacosi, M.L. , Morelli, S. , Bini, V. , Ambrosi, B. , Giordano, R. , Perniola, R. ,De Bellis, A. , Betterle, C. , Falorni, A. (2010). Autoantibody responses in autoimmune ovarian insufficiency and in Addison's disease are IgG1 dominated and suggest a predominant, but not exclusive, Th1 
type of response. European Journal of Endocrinology. Vol. 163, No. 2., pp 309-317, ISSN 08044643

Bukulmez, O. \& Arici, A. (2000). Leukocytes in ovarian function. Human Reproduction Update. Vol. 6, No. 1, pp. 1-15, ISSN 1460-2369

Buttari,B., Profumo, E., Mattei, V., Siracusano, A., Ortona, E., Margutti, P., Salvati, B., Sorice, M. \& Riganò, R. (2005). Oxidized beta2-glycoprotein I induces human dendritic cell maturation and promotes a T helper type 1 response. Blood. Vol. 106, No. 12, pp. 3880-3887, ISSN 1528-0020

Calongos, G., Hasegawa, A., Komori, S. \& Koyama, K. (2009). Harmful effects of anti-zona pellucida antibodies in folliculogenesis, oogenesis, and fertilization. Journal of Reproductive Immunology. Vol. 79, No. 2, pp. 148-155, ISSN 0165-0378.

Carbone, M., Tatone, C., Delle Monache, S., Marci, R., Caserta, D., Colonna, R. \& Amicarelli F. (2003). Antioxidant enzymatic defences in human follicular fluid: characterization and age dependent changes. Molecular Human Reproduction. Vol. 9, No. 11, pp. 639-643, ISSN 1460-2407

Chang, M., Lowe, D., Lewis, M., Hellmiss, R., Chen, E. \& Goeddel DV (1989). Differential activation by atrial and brain natriuretic peptides of two different receptor guanylate cyclases. Nature. Vol. 346, pp. 68-72, ISSN 0028-0836

Chatterjee, S., Modi, D., Maitra, A., Kadam, S., Patel, Z., Gokrall, J. \& Meherji, P. (2007). Screening for FOXL2 gene mutations in women with premature ovarian failure: an Indian experience. Reproductive Biomedicine Online. Vol.15, No. 5, pp. 554-560, ISSN 1472-6491

Chen, J, Liu, Y., Liu, H., Hermonat, \& P., Mehta, J. (2006). Molecular dissection of angiotensin II-activated human LOX-1 promoter. Arteriosclerosis, Thrombosis and Vascular Biology. Vol. 26, No 5, pp.1163-1168. ISSN: 10795642

Chen, S., Sawicka, J., Betterle, C., Powell, M., Prentice, L., Volpato, M., Rees Smith, B. \& Furmaniak, J. (1996). Autoantibodies to steroidogenic enzymes in autoimmune polyglandular syndrome, Addison's disease, and premature ovarian failure. Journal of Clinical Endocrinology \& Metabolism. Vol. 81, No. 5, pp. 1871-1876, ISSN 1945-7197

Chernyshov,V., Radysh,T., Gura, I., Tatarchuk, T. \& Khominskaya, Z.(2001). Immune disorders in women with premature ovarian failure in initial period. American Journal of Reproductive Immunology. Vol. 46, No. 3, 220-225, ISSN 1600-0897

Chun, S., Eisenhauer, K. \& Minami, S. (1996). Hormonal regulation of apoptosis in early antral follicles: follicle- stimulating hormone as a major survival factor. Endocrinology. 1996; Vol. 137, No. 4, pp. 1447-1456. IISSN 1945-7170

Cianci, A., Calogero, AE., Palumbo, M., Burrello, N., Ciotta, L., Palumbo, G. \& Bernardini, R. (1996). Relationship between tumour necrosis factor alpha and sex steroid concentrations in the follicular fluid of women with immunological infertility. Human Reproduction. Vol. 11, No. 2, pp. 265-268, ISSN 1460-2350

Dal Pra, C., Chen, S., Furmaniak, J., Smith, B., Pedini, B., Moscon, A., Zanchetta, R. \& Betterle, C. (2003). Autoantibodies to steroidogenic enzymes in patients with premature ovarian failure with and without Addison's disease. Europian Journal of Endocrinology. Vol. 148, No. 5, pp. 565-570, ISSN 1479-683X 
Damewood, M., Zacur, H., Hoffman, G. \& Rock, J.(1986). Circulating antiovarian antibodies in premature ovarian failure. Obstetrics and Gynecology. Vol. 68, No. 6, pp. 850-854, ISSN 0029-7844

Davis, J. \& Rueda, B. (2002) The corpus luteum: an ovarian structure with maternal instincts and suicidal tendencies. Frontiers in Bioscience. Vol. 7, pp. 1949-1978, ISSN 1093-4715

Di Donato A., Lacal J., Di Duca, M., Giampuzzi, M., Chiggeri, G., \& Gusmano, R. (1997). Micro-injection of recombinant lysyl oxidase blocks oncogenic p21-Ha-Ras and progesterone effects on Xenopus laevis oocyte maturation. FEBS Letters, Vol. 419, No1, pp. 63-68, ISSN: 00145793

Dineva, J., Vangelov, I., Nikolov, G., Gulenova, D. \& Ivanova, M. (2006). Apoptosis of human Granulosa Luteinized (GLCs) and Cumulus Cells (CCs) as a possible indicator for IVF outcome. Comptes rendus de l'Acad'emie bulgare des Sciences. Vol. 59, No.7, pp. 781-784. ISSN 1310-1331

Dineva, J., Wójtowicz, A. Augustowska, K., Vangelov, I., Gregoraszczuk, E. \& Ivanova, M. (2007). Expression of Atrial Natriuretic Peptide (ANP), Progesterone (P), Apoptosis-Related Proteins (bcl-2, p53) and Caspase-3 Activity in in vitro Luteinized and Leptin-Treated Porcine Granulosa Cells (pGLCs). Enodocrine Regulations. Vol. 41, No. 1, 2006, pp.11-18, ISSN 1336-0329

Doherty, E., Pakarinen, P., Tiitinen, A., Kiilavuori, A., Huhtaniemi, I., Forrest, S. \& Aittomäki, K. (2002). Novel mutation in the FSH receptor inhibiting signal transduction and causing primary ovarian failure. Journal of Clinical Endocrinology $\mathcal{E}$ Metabolism. Vol. 87, No. 3, pp. 1151-1155, ISSN 1945-7197

Du Plessis, S., Desai, M. \& Agarwal A (2008) The impact of oxidative stress on in vitro fertilization. Expert Review of Obstetrics and Gynecology.Vol. 3, No. 4, pp. 359-554, ISSN: 1747-4108

Ebner, T., Moser, M., Sommergruber, M., Tews, G. (2003). Selection based on morphological assessment of oocytes and embryos at different stages of preimplantation development: a review. Human Reproduction Update. Vol.9, No 3, pp251-262. ISSN: 13554786

Edassery, S., Shatavi, S., Kunkel, J., Hauer, C., Brucker, C., Penumatsa, K., Yu, Y., Dias, J. \& Luborsky, J. (2010). Autoantigens in ovarian autoimmunity associated with unexplained infertility and premature ovarian failure. Fertility and Sterility. Vol. 94, No. 7, pp. 2636-2641, ISSN 1556-5653

Eppig, J. (2001). Oocyte control of ovarian follicular development and function in mammals. Reproduction. Vol. 122, No6, pp. 829-838, ISSN 14701626

Falorni, A., Laureti, S., Candeloro, P., Perrino, S., Coronella, C., Bizzarro, A., Bellastella, A., Santeusanio, F. \& De Bellis, A. (2002). Steroid-cell autoantibodies are preferentially expressed in women with premature ovarian failure who have adrenal autoimmunity. Fertility and Sterility. Vol. 78, No. 2, pp. 270-279, ISSN 1556-5653

Fénichel, P., Sosset, C., Barbarino-Monnier, P., Gobert, B., Hiéronimus, S., Béné, M. \& Harter, M. (1997). Prevalence, specificity and significance of ovarian antibodies during spontaneous premature ovarian failure. Human Reproduction. Vol.12, No. 12, pp. 2623-2628, ISSN 1460-2350 
Forges, T., Monnier-Barbarino, P., Faure, G. \& Béné, M. (2004). Autoimmunity and antigenic targets in ovarian pathology. Human Reproduction Update. Vol. 10, No. 2, pp. 163-75. ISSN 1460-2369

Ghazeeri, G. \& Kutteh, W. (2001). Autoimmune factors in reproductive failure. Current Opinion in Obstetrics and Gynecology. Vol. 13, pp. 287-291, ISSN 1473-656X.

Gilmore TD. (2006). Introduction to NF-kB: Players, pathways, perspectives. Oncogene Vol. 25, No 51, pp. 6680-6684. ISSN: 09509232

Gobert, B., Barbarino-Monnier, P., Guillet-May, F., Béné, M. \& Faure G. (1992). Anti-ovary antibodies after attempts at human in-vitro fertilization induced by follicular puncture rather than hormonal stimulation. Journal of Reproduction and Fertilitity. Vol. 96, No. 1, pp. 213-218, ISSN 0022-4251

Gobert, B., Jolivet-Reynaud, C., Dalbon, P., Barbarino-Monnier, P., Faure, G. Jolivet, M. \& Béné, M. (2001). An immunoreactive peptide of the FSH involved in autoimmune infertility. Biochemical and Biophysical Resarch Communications. Vol. 289, No.4, pp. 819-824, ISSN 0006-291X

Gutkowska, J., Jankowski, M., Sairam M., Fujio, N., Reis, A., Mukaddam-Daher S. \& Tremblay, J. (1999). Hormonal regulation of natriuretic peptide system during induced ovarian follicular development in the rat. Biology of Reproduction. Vol. 61, No. 1, 162-170, ISSN 1529-7268

Gutkowska, J., Tremblay, J., Antakly T., Meyer, R., Mukaddam-Daher, S. \& Nemer, M. (1993). The atrial natriuretic peptide system in rat ovaries. Endocrinology. Vol. 132, No. 2, pp. 693-700, ISSN 1945-7170

Haller, K., Mathieu, C., Rull, K., Matt, K., Béné, M. \& Uibo R. (2005). IgG, IgA and IgM antibodies against FSH: serological markers of pathogenic autoimmunity or of normal immunoregulation? American Journal of Reproductive Immunology. Vol. 54, No. 5, pp. 262-269, ISSN 1600-0897

Hämäläinen, E. Jones, T., Sheer, D., Taskinen, K., Pihlajaniemi, T., \& Kivirikko, K. (1991). Molecular cloning of human lysyl oxidase and assignment of the gene to chromosome 5q23.3-31.2. Genomics, Vol. 11, No 3, pp. 508-516. ISSN: 08887543

Harlow, C., Rae, M., Davidson, L., Trackman, P., \& Hillier, S. (2003). Lysyl Oxidase Gene Expression and enzyme activity in the rat ovary: regulation by follicle-stimulating hormone, androgen and transforming growth factor beta superfamily members in vitro. Endocrinology. Vol. 144, No 1, pp. 154-162. ISSN: 00137227

Hawa, M., Fava, D., Medici, F., Deng, Y., Notkins, A., De Mattia, G. \& Leslie, R. (2000). Antibodies to IA-2 and GAD65 in type 1 and type 2 diabetes: isotype restriction and polyclonality. Diabetes Care. Vol. 23, No. 2, pp. 228-33, ISSN 1935-5548

Ho, P., Tang, G., Fu, K., Fan, M. \& Lawton, J. (1988). Immunologic studies in patients with premature ovarian failure. Obstetrics and Gynecology. Vol. 71, No. 4, pp. 622-626, ISSN 0029-7844

Hoek, A., van Kasteren, Y., de Haan-Meulman, M., Hooijkaas, H., Schoemaker, J. \& Drexhage, H.(1995). Analysis of peripheral blood lymphocyte subsets, NK cells, and delayed type hypersensitivity skin test in patients with premature ovarian failure. American Journal of Reproductive Immunology. Vol. 33, No. 6, pp. 495-502, ISSN 1600-0897 
Hoek, A., Schoemaker, J. \& Drexhage, H. (1997). Premature ovarian failure and ovarian autoimmunity. Endocrine Reviews. Vol. 18, No1, pp. 107-134, ISSN 0163-769X.

Hoek, A., van Kasteren, Y., de Haan-Meulman, M., Schoemaker, J. \& Drexhage, H.A. (1993). Dysfunction of monocytes and dendritic cells in patients with premature ovarian failure. American Journal of Reproductive Immunology. Vol. 30, No. 4, pp. 207-217, ISSN 1600-0897

Horejsí, J., Martínek, J., Nováková, D., Madar, J. \& Brandejska, M. (2000). Autoimmune antiovarian antibodies and their impact on the success of an IVF/ET program. Annals of the New York Academy of Science. Vol. 900, pp. 351-356, ISSN 0077-8923.

Host, E., Mikkelsen, A. Lindenberg, S. \& Smidt-Jensen S. (2000). Apoptosis in human cumulus cells in relation to maturation stage and cleavage of the corresponding oocyte. Acta Obstetrica et Gynecology Scandinavica. Vol. 79, No. 11, pp. 936-940, ISSN 1600-0412

Huang, Q., Liu, Q. \& Wu, J. (1996). Determinations of antiovarian antibodies and cellular immunity functions in patients with premature ovarian failure. Chinese Journal of Obstetrics and Gynecology.Vol. 31, No. 10, pp. 603-605, ISSN 0529-567

Iñarrea, P., Moini, H., Han, D., Rettori, D., Aguiló, I., Alava, M., Iturralde, M. \& Cadenas E. (2007). Mitochondrial respiratory chain and thioredoxin reductase regulate intermembrane $\mathrm{Cu}, \mathrm{Zn}$-superoxide dismutase activity: implications for mitochondrial energy metabolism and apoptosis. Biochemical Journal. Vol. 405, pp. 173-179. ISSN 1470-8728

Ivanova, M. \& Mollova, M. Zona-penetration in vitro test for evaluating boar sperm fertility (1993) Theriogenology. Vol. 40, No. 2, pp. 397- 410, ISSN 0093-691X

Ivanova, M., Bourneva, V., Gitsov, L. \& Angelova, Z. (1984). Experimental immune oophoritis as a model for studying the thymus-ovary interaction: 1. Morphological studies. American Journal of Reproductive Immunology. Vol. 6, No. 3, pp. 99-106, ISSN 1600-0897

Ivanova, M., Gregoraszczuk, E., Augustowska, K., Kolodziejczyk, J., Mollova, M. \& Kehayov IR. (2003). Localization of atrial natriuretic peptide in pig granulosa cells isolated from ovarian follicles of various size. Reproductive Biology. Vol. 3, No. 2, pp. 173-181, ISSN 1529-7268

Jiang, J., Xiong, H., Cao, M., Xia, X., Sirard, M., \& Tsang, B. (2010) Mural granulosa cell gene expression associated with oocyte developmental competence. Journal of Ovarian Research, Vol. 3, No 1:6, ISSN: 17572215

Kably Ambe, A., Ruiz Anguas, J., Carballo Mondragón, E. \& Karchmer Krivitsky S. (2005) Intrafollicular levels of sexual steroids and their relation with the antioxidant enzymes on the oocyte quality in an in vitro fertilization program. Ginecology Obstetrics Mexico. Vol. 73, No. 1, pp. 19-27, ISSN 0014-4142

Kannan, S. (2006). Free radical theory of autoimmunity. Theoretical Biology and Medical Modeling. Vol. 3, No.22, ISSN 1742-4682

Kelkar, R., Meherji, P, Kadam, S., Gupta, S. \& Nandedkar, T. (2005). Circulating autoantibodies against the zona pellucida and thyroid microsomal antigen in women with premature ovarian failure. Journal of Reproductive Immunoogy. Vol. 66, No.1, pp. 53-67, ISSN 0165-0378. 
Kendall N., Marsters, P., Scaramuzzi, R, \& Campbell, B. (2003). Expression of lysyl oxidase and effect of copper chloride and ammonium tetrathiomolybdate on bovine ovarian follicle granulosa cells cultured in serum-free media. Reproduction, Vol. 125, No 5, pp. 657-665. ISSN: 14701626

Kiemer, A. \& Vollmar A. (2001). Elevation of intracellular calcium levels contributes to the inhibition of inducible nitric oxide synthase by atrial natriuretic peptide. Immunology and Cell Biology. Vol. 79, pp. 11-17, ISSN 1440-1711

Kiemer, A., Hartung, T. \& Vollmar, A. (2000). cGMP-mediated inhibition of TNF-a production by the atrial natriuretic peptide in murine macrophages. Journal of Immunology. Vol. 165, No. 1, pp. 175-181, ISSN 1550-6606

Kim, S., Shinjo, M., Usuki S., Tada,M., Miyazaki, H. \& Murakami, K. (1987). Binding sites for atrial natriuretic peptide in high concentration in human ovaries. Biomedical Research. Vol. 8, pp. 415-420, ISSN 0970938X

Kovalevsky, G. \& Patrizio, P. (2005) High rates of embryo wastage with use of assisted reproductive technology: A look at the trends between 1995 and 2001 in the United States Fertility and Sterility., Vol. 84 ,No2, pp. 325-330, ISSN 00150282

Koyama, K. (2010). Anti-gonad antibodies, anti-sperm antibodies. Nihon Rinsho. Vol. 68, No. 6, pp. 622-624. ISSN 0047-1852.

Kregel, K. \& Zhang, H. (2007). An integrated view of oxidative stress in aging: basic mechanisms, functional effects, and pathological considerations. American Journal of Physiology. Vol. 292, No.1, pp. 18-36, ISSN 1522-1490

Krumova, E., Dolashka-Angelova, P., Pashova, S., Stefanova, L., Van Beeumen, J., Vassilev, S. \& M. Angelova (2007). Improved production by fed-batch cultivation and some properties of $\mathrm{Cu} / \mathrm{Zn}$-superoxide dismutase from the fungal strain Humicola lutea 103. Enzyme and Microbial Technology. Vol. 40, No. 4, pp. 524-532, ISSN 0141-0229

Kumar, S., Ma, B., Tsai, C., Wolfson, H., \& Nussinov, R. (1999). Folding funnels and conformational transitions via hinge-bending motions. Cellular Biochemistry and Biophysics. Vol. 31, No2, pp: 141-164. ISSN: 10859195

Kuno, N., Kadomatsu, Fan, K., Hagihara Q., Senda, T., Mizutani, S., \& Muramatsu, T. (1998). Female sterility in mice lacking the basigin gene, which encodes a transmembrane glycoprotein belonging to the immunoglobulin superfamily. FEBS Lett. Vol. 425, No 2, pp. 191-194. ISSN: 00145793

Kyurkchiev, S., Surneva-Nakova, T., Ivanova, M., Nakov, L. \& Dimitrova, E. (1988). Monoclonal antibodies to porcine zona pellucida that block the initial stages of fertilization. American Journal of Reproductive Immunology and Microbiology. Vol. 18, No. 1, pp. 11-16, ISSN 8755-8920

La Marca, A., Brozzetti, A., Sighinolfi, G., Marzotti, S., Volpe, A. \& Falorni A. (2010). Primary ovarian insufficiency: autoimmune causes. Current Opinion in Obstetrics and Gynecology. Vol. 22, No. 4, pp. 277-82. ISSN 1473-656X.

La Polt Ps., Leung, K., Ishimaru, R., Tafoya, M. \& Chen J. (2003). Roles of cyclic GMP in modulating ovarian functions. Reproductive Biomedicine Online, Vol. 6, No.1, pp.1523, ISSN 1472-6491

Lee, K., Joo, B., Yong, J., Yoon, M., Choi, O. \& Kim, W. (2001). Cumulus Cells Apoptosis as an Indicator to Predict the Quality of Oocytes and the Outcome of IVF-ET. Journal of Assisted Reproduction and Genetics. Vol. 18, No. 9, pp. 490-498, ISSN 1573-7330 
Lefèvre, B. (2011). Follicular atresia: Its features as predictive markers for the outcome of assisted reproduction. Gynecologie Obstetrique Fertilite. Vol. 39, No. 1, pp. 58-62, ISSN 1769-6682

Li, D., \& Mehta, J. (2000). Upregulation of endothelial receptor for oxidized LDL (LOX-1) by oxidized LDL and implications in apoptosis of coronary artery endothelial cells: Evidence from use of antisense LOX-1 mRNA and chemical inhibitors. Arteriosclerosis, Thrombosis, and Vascular Biology. Vol. 20, No 4, pp. 1116-22, ISSN 1079-5642

Li, J., Jin, H., Zhang, F., Du, X., Zhao, G., Yu, Y. \& Wang, B. (2008). Treatment of autoimmune ovarian disease by co-administration with mouse zona pellucida protein 3 and DNA vaccine through induction of adaptive regulatory $\mathrm{T}$ cells. Journal of Gene Medicine. Vol. 10, 7, pp. 810-20, ISSN 1521-2254

Li, Q., Sato, E., Kira, Y., Nishikawa, M., Utsumi, K. \& Inoue M., (2006). A possible cooperation of SOD1 and cytochrome $\mathrm{C}$ in mitochondria-dependent apoptosis. Free Radical Biology and Medicine. Vol. 40, No. 1, pp.173-181, ISSN 0891-5849

Li, Q., Sato, E., Zhu, X. \& Inoue M. (2009) A simultaneous release of SOD1 with cytochrome $\mathrm{C}$ regulates mitochondria-dependent apoptosis. Molecular and Cellular Biochemistry. Vol. 322, No. 1-2, pp. 151-159, ISSN 1573-4919

Li, W., Nellaiappan, K., Strassmaier, T., Graham, L., Thomas, K., \& Kagan, H. (1997). Localization and activity of lysyl oxidase within nuclei of fibrogenic cells. Proc Natl Acad Sci USA, Vol. 94, No24, pp.12817-12822, ISSN 00278424

Lloyd, M., Papadimitriou, J., O'Leary, S., Robertson, S. \& Shellam, G.R. (2010). Immunoglobulin to zona pellucida 3 mediates ovarian damage and infertility after contraceptive vaccination in mice. Journal of Autoimmunity. Vol. 35, No. 1, pp. 77-85, ISSN 0896-8411

Luborsky, J. (2002).Ovarian autoimmune disease and ovarian autoantibodies. Journal of Womens Health and Gender Based Medicine. Vol. 11, No. 7, pp. 585-99, ISSN 1931-843X

Luborsky, J., Llanes, B., Davies, S., Binor, Z., Radwanska, E. \& Pong, R. (1999). Ovarian autoimmunity: greater frequency of autoantibodies in premature menopause and unexplained infertility than in the general population. Clinical Immunology. Vol. 90, No. 3, pp. 368-74, ISSN 1521-6616

Luborsky, J., Llanes, B., Roussev, R.\& Coulam C. (2000). Ovarian antibodies, FSH and inhibin B: independent markers associated with unexplained infertility. Human Reprodoction. Vol. 15, No. 5, pp. 1046-51, ISSN 1460-2350

Luborsky, J., Visintin, I., Boyers, S., Asari, T., Caldwell, B. \& DeCherney, A. (1990). Ovarian antibodies detected by immobilized antigen immunoassay in patients with premature ovarian failure. Journal of Clinical Endocrinology \& Metabolism. Vol.70, No. 1, pp. 69-75, ISSN 1945-7197

Luborsky, J.L., Yu, Y., Edassery, S., Jaffar, J., Yip, Y., Liu, P., Hellstrom, K.\& Hellstrom, I.(2011). Autoantibodies to mesothelin in infertility. Cancer Epidemiology, Biomarkers and Prevention. Vol. 20, No. 9, pp. 1970-1978, ISSN 1538-7755

Maity, R., Nair, S., Caspi, R.. \& Nelson, L. (1997). Post-thymectomy murine experimental autoimmune oophoritis is associated with reduced natural killer cell activity. American Journal of Reproductive Immunology. Vol. 38, No. 5, pp. 360-5, ISSN 16000897 
Mande, P.V., Parikh, F., Hinduja, I., Zaveri, K., Vaidya, R., Gajbhiye, R. \& Khole, V. (2011). Identification and validation of candidate biomarkers involved in human ovarian autoimmunity. Reproductive Biomedicine Online. ISSN 1472-6491

Mardesic, T., Ulcova-Gallova, Z., Huttelova, R., Muller, P., Voboril, J., Mikova, M. \& Hulvert, J. (2000). The influence of different types of antibodies on in vitro fertilization results. American Journal of Reproductive Immunology. Vol. 43, No. 1, pp. 1-5, ISSN 1600-0897

Mathur, S., Peress, M., Williamson, H., Youmans, C., Maney, S., Garvin, A., Rust, P. \& Fudenberg, H. (1982). Autoimmunity to endometrium and ovary in endometriosis. Clinical and Experimental Immunology. Vol. 50, No. 2, pp. 259-266, ISSN 1365-2249

Matos, L., Stevenson, D., Gomes, F., Silva-Carvalho, J. \& Almeida, H. (2009). Superoxide dismutase expression in human cumulus oophorus cells. Molecular Human Reprodoction. Vol.15, No. 7, pp. 411-419, ISSN 1460-2407

McNatty, K., Moore, L., Hudson, N., Quirke, L., Lawrence, S., Reader, K., Hanrahan, J., Smith, P., Groome, N., Laitinen, M., Ritvos, O., \& Juengel, J. (2004). The oocyte and its role in regulating ovulation rate: a new paradigm in reproductive biology. Reproduction, Vol. 128, No 4, pp: 379-386, ISSN: 14701626

Medzhitov, R. (2010). Inflammation 2010: new adventures of an old flame. Cell. Vol. 140, No. 6, pp. 771-6, ISSN 0092-8674

Mignot, M., Drexhage, H., Kleingeld, M., Van de Plassche-Boers, E.M., Rao, B. \& Schoemaker, J.(1989). Premature ovarian failure. II: Considerations of cellular immunity defects. Europian Journal of Obstetrics \& Gynecology \& Reproductive Biology. Vol. 30, No. 1, pp. 67-72, ISSN 1872-7654

Miyauchi, T., Masuzawa, Y., \& Muramatsu, T. (1991). The basigin group of the immunoglobulin superfamily: complete conservation of a segment in and around transmembrane domains of human and mouse basigin and chicken HT7 antigen Journal of Biochemistry., Vol. 110, No 5, pp.770-774. ISSN: 0021924X

Moncayo-Naveda, H., Moncayo, R., Benz, R., Wolf, A. \& Lauritzen C. (1989). Organ-specific antibodies against ovary in patients with systemic lupus erythematosus. American Journal of Obstetrics and Gynecology. Vol. 160, No. 5, pp. 1227-1229, ISSN 0002-9378

Mouatassim S., Guérin, P. \& Ménézo, Y. (1999). Expression of genes encoding antioxidant enzymes in human and mouse oocytes during the final stages of maturation. Molecular Human Reprodoction. Vol. 5, No. 8, pp. 720-725, ISSN 1460-2407

Nakahara, K., Saito, H., Saito, T., Ito, M., Ohta, N., Sakai, N., Tezuka, N,. Hiroi, M. \& Watanabe, H. (1997). The incidence of apoptotic bodies in membrana granulosa can predict prognosis of ova from patiens participating in in vitro fertilization programs. Fertility and Sterility. Vol. 68, No. 2, 312-317, ISSN 1556-5653

Navratil, J., Sabatine, J. \& Ahearn, J. (2005). Apoptosis and immune responses to self. Rheumatic Disease Clinics of North America. Vol. 30, No. 1, pp. 193-212, ISSN 15583163

Nelson, L. (2009). Clinical practice. Primary ovarian insufficiency. The New England Journal of Medicine. Vol. 360, No. 6, pp. 606-614, ISSN 1533-4406

Ntrivalas, E., Kwak-Kim, J., Gilman-Sachs, A., Chung-Bang, H., Ng, S., Beaman, K., Mantouvalos, H. \& Beer, A. (2001). Status of peripheral blood natural killer cells in 
women with recurrent spontaneous abortions and infertility of unknown aetiology. Human Reprodoction. Vol. 16, No. 5, pp. 855-861, ISSN 1460-2350

Orrenius, S., Gogvadzejavas V. \& Zhivotovsky B. (2007). Mitochondrial Oxidative Stress: Implications for Cell Death. Pharmacology and Toxicolology. Vol. 47, pp. 143-183, ISSN 1600-0773

Paciolla, M., Boni, R., Fusco, F., Pescatore, A., Poeta, L., Ursini, M., Lioi, M. \& Miano, M. (2011). Nuclear factor-kappa-B-inhibitor alpha (NFKBIA) is a developmental marker of NF-kB/p65 activation during in vitro oocyte maturation and early embryogenesis. Human Reproduction. Vol. 26, No 5, ISSN: 02681161

Papachroni, K., Piperi, C., Levidou, G., Korkolopoulou, P., Pawelczyk, L., DiamantiKandarakis, E., \& Papavassiliou, A. (2010). Lysyl oxidase interacts with AGE signalling to modulate collagen synthesis in polycystic ovarian tissue. Journal of Cellular and Molecular Medicine., Vol. 14, No 10, pp. 2460-2469 ISSN: 15821838

Pasoto, S., Viana, V., Mendonca, B., Yoshinari, N. \& Bonfa, E. (1999). Anti-corpus luteum antibody: a novel serological marker for ovarian dysfunction in systemic lupus erythematosus. Journal of Rheumatology. Vol. 26, No. 5, pp. 1087-93, ISSN 1499-2752

Pasqualotto, E., Lara, L., Salvador, M., Sobreiro, B., Borges, E. \& Pasqualotto F. (2009). The role of enzymatic antioxidants detected in the follicular fluid and semen of infertile couples undergoing assisted reproduction. Human Fertilility (Cambridge). Vol. 12, No. 3, 166-71, ISSN 1464-7273

Petríková, J., Lazúrová, I., Yehuda, S. (2010). Polycystic ovary syndrome and autoimmunity. European Journal of International Medicine. Vol. 21, No. 5, pp.369-371, ISSN 0953-6205

Piccinni, M., Beloni, L., Livi, C., Maggi, E., Scarselli, G. \& Romagnani, S. (1998). Defective production of both leukemia inhibitory factor and type 2 T-helper cytokines by decidual $\mathrm{T}$ cells in unexplained recurrent abortions. Nature Medicine. Vol. 4, No. 9, pp.1020-1024, ISSN 1546-170X

Pires, E., Meherji, P., Vaidya, R., Parikh, F., Ghosalkar, M. \& Khole V. (2007). Specific and sensitive immunoassays detect multiple anti-ovarian antibodies in women with infertility. Journal of Histochemistry and Cytochemistry. Vol. 55, No. 12, pp.1181-1190, ISSN 1551-5044

Pires, E., Parte, P., Meherji, P., Khan, S. \& Khole V. (2006). Naturally occurring anti-albumin antibodies are responsible for false positivity in diagnosis of autoimmune premature ovarian failure. Journal of Histochemistry and Cytochemistry. Vol. 54, No. 4, pp. 397-405, ISSN 1551-5044

Prado-Drayer, A., Teppa, J., Sánchez, P. \& Camejo, M. (2008). Immunophenotype of peripheral T lymphocytes, NK cells and expression of CD69 activation marker in patients with recurrent spontaneous abortions, during the mid-luteal phase. American Journal of Reproductive Immunology. Vol. 60, No.1, pp. 66-74, ISSN 16000897

Puddu, P., Puddu, G., Cravero, E., De Pascalis, S. \& Muscari, A. (2009). The emerging role of cardiovascular risk factor-induced mitochondrial dysfunction in atherogenesis. Journal of Biomedical Science. Vol. 6, p. 112, ISSN 1423-0127

Ramasamy, R., Yan, S. \& Schmidt, A. (2009). RAGE: therapeutic target and biomarker of the inflammatory response - the evidence mounts. Journal of Leukocyte Biology. Vol. 86, No. 3, pp. 505-512, ISSN 1938-3673 
Rhoades, K., Golub, S, \& Economou J. (1992). The regulation of the human tumor necrosis factor alpha promoter region in macrophage, $\mathrm{T}$ cell, and $\mathrm{B}$ cell lines. The Journal of Biological Chemistry. Vol. 267, No. 31, 22102-22107, ISSN 1083-351X

Richards, J., Russell, D., Ochsner, S. \& Espey, L. (2002). Ovulation: new dimensions and new regulators of the inflammatory-like response. Annual Review of Physiology. 2002, 64, pp. 69-92, ISSN 00664278

Rivest, S. \& Rivier, C. (1995). The role of corticotropin-releasing factor and interleukin-1 in the regulation of neurons controlling reproductive functions. Endocrine Reviews. Vol. 16, No. 2, pp. 177-99, ISSN 1945-7189

Rock, K., Latz, E., Ontiveros, F. \& Kono, H. (2010). The sterile inflammatory response. Annual Review of Immunology. Vol. 28, pp. 321-42, ISSN 0066-4162

Russinova, A., Mourdjeva, M., Kyurkchiev, S. \& Kehayov, I. (2001). Immunohistochemical detection of atrial natriuretic factor (ANF) in different ovarian cell types. Endocrine Regulations. Vol 35, No. 2, pp. 81-89, ISSN 1336-0329.

Samson, W., Aguila, M. \& Bianchi R. (1988). Atrial natriuretic factor inhibits luteinizing hormone secretion in the rat: evidence for a hypothalamic site of action. Endocrinology. Vol. 122, No. 4, pp. 1573-82, ISSN 1945-7170

Schwartz, D., Geller, D., Manning, P., Siegel, N., Fok, K., Smith, C. \& Needleman P. (1984). Ser-Leu-Arg-Arg-atriopeptin III: the major circulating form of atrial peptide. Science. Vol. 229, No. 4711, pp. 397-400, ISSN 1095-9203

Seifer, D., Gradiner, A., Ferreria, K. \& Peluso, J. (1996). Apoptosis as a function of ovarian reserve in women undergoing in vitro fertilization. Fertility and Sterility. Vol. 66, No. 4, pp. 593-598, ISSN 1556-5653

Seino, T., Saito, H., Kaneko, T., Takahashi, T., Kawachiy, S. \& Kurachi, H. (2002). Eighthydroxy-2'-deoxyguanosine in granulosa cells is correlated with the quality of oocytes and embryos in an in vitro fertilization-embryo transfer program. Fertility and Sterility. Vol. 77, No. 6, pp. 1184-1190, ISSN 1556-5653

Serke, H., Bausenwein, J., Hirrlinger, J., Nowicki, M., Vilser, C., Jogschies, P., Hmeidan, F., Blumenauer,V. \& Spanel-Borowski, K. (2010). Granulosa cell subtypes vary in response to oxidized low-density lipoprotein as regards specific lipoprotein receptors and antioxidant enzyme activity. Journal of Clinical Endocrinology $\mathcal{E}$ Metabolism. Vol. 95, No. 7, pp. 3480-90, ISSN 021-972

Serke, H., Vilser, C., Nowicki, M., Hmeidan, F., Blumenauer,V., Hummitzsch, K., Losche, A. \& Spanel-Borowski, K. (2009). Granulosa cell subtypes respond by autophagy or cell death to oxLDL-dependent activation of the oxidized lipoprotein receptor 1 and toll-like 4 receptor. Autophagy.Vol. 5 , pp. 991-1003, ISSN 1554-8635

Sica, A., Dorman, L., Viggiano, V., Ghosh, P., Rice, N. \& Young, H. (1997). Interaction of NF$\mathrm{B}$ and NFAT with the Interferon- Promoter. The Journal of Biological Chemistry. Vol. 272, No. 48, pp. 30412-30420, ISSN 1083-351X

Singer-Sam, J., Keith, D. Tani, K., Simmer, R. Shively, L., Lindsay, S. Yoshida, A \& Riggs, A. (1984). Sequence of the promoter region of the gene for human X-linked 3phosphoglycerate kinase. Gene, Vol. 32 , No 3, pp.409-417. ISSN: 03781119

Smedts, A., \& Curry, T. (2005). Expression of basigin, an inducer of matrix metalloproteinases, in the rat ovary. Biology of Reproduction., Vo. 73, No1, pp.80-87. ISSN: 00063363 
Spanel-Borowski, K. (2011). Footmarks of innate immunity and cytokeratin-positive cells as potential dendritic cells. Advances in Anatomy, Embryology and Cell Biology. Vol 209, Springer Heidelberg. ISBN 978-3-642-16076-9.

Suh, Ch., Jee, B., Choi, Y., Kim, J., Lee, J., Moon, S. \& Kim, S. (2002). Prognostic Implication of Apoptosis in Human Luteinized Granulosa Cells During IVF-ET. Journal of Assisted Reproduction and Genetics. Vol. 19, No. 5, pp. 209-214, ISSN 1058-0468

Sundblad, V., Bussmann, L., Chiauzzi, V., Pancholi, V. \& Charreau, E. (2006). a-enolase: a novel autoantigen in patients with premature ovarian failure. Clinical Endocrinology. Vol. 65, pp. 745-751, ISSN 1365-2265

Suzuki, T., Sugino, N., Fukaya, T., Sugiyama, S., Uda, T., Takaya, R., Yajima, A. \& Sasano, H. (1999). Superoxide dismutase in normal cycling human ovaries: immunohistochemical localization and characterization. Fertility and Sterility. Vol. 72, No. 4, pp. 720-726, ISSN 1556-5653

Takuma, K., Phuagphong, P., Lee, E., Mori, K., Baba, A. \& Matsuda T. (2001). Anti-apoptotic Effect of cGMP in Cultured Astrocytes: inhibition by cGMP-dependent protein kinase of mitochondrial permeable transition. The Journal of Biological Chemistry. Vol. 276, No. 51, pp. 48093-48099, ISSN 1083-351X

Tatone, C., Carbone, M., Falone, S., Aimola, P., Giardinelli, A., Caserta, D., Marci, R., Pandolfi, A., Ragnelli, A. \& Amicarelli, F. (2006). Age-dependent changes in the expression of superoxide dismutases and catalase are associated with ultrastructural modifications in human granulosa cells. Molecular Human Reprodoction. Vol. 12, No. 11, pp. 655-60, ISSN 1460-2407

Teede, H., Deeks, A.\& Moran, L (2010). Polycystic ovary syndrome: a complex condition with psychological, reproductive and metabolic manifestations that impacts on health across the lifespan. BMC Medicine. Vol. 30, pp. 8-41. ISSN 1741-7015

Tilly, Y., Kowalski K., Yohanson A. \& Hsueh A. (1991) Involvement of apoptosis in ovarian follicular atresia and postovulatory regression. Endocrinology. Vol. 129, No. 5, pp. 2799-2801, ISSN 1945-7170

Todorova, K., Vangelov, I., Dineva, J., Penchev, V., Hayrabedyan, S., Nikolov, G., Mollova, M., Ivanova, M. (2011). Lysyl Oxidase as a Potential Biomarker for Predicting Oocyte Quality. Comptes rendus de l'Acade'mie bulgare des Sciences. Vol. 64, No9, pp. 1355-1362. ISSN 1310-1331

Todorova, K., Zasheva, D., Hayrabedyan, S, Dineva, J, Vangelov, I, Penchev, V., Nikolov, G., Mollova, M., Ivanova, M. (2011). Gene Panel in Human Cumulus Cells as Biomarker for Successful in vitro Procedures. Comptes rendus de l'Acade'mie bulgare des Sciences. Vol. 64, No8, pp. 1143-1150. ISSN 1310-1331

Tong, Z. \& Nelson, L. (1999). A mouse gene encoding an oocyte antigen associated with autoimmune premature ovarian failure. Endocrinology. Vol. 140, No. pp. 83720-3726

Törnell, J., Carlsson, B. \& Billig, H. (1990). Atrial natriuretic peptide inhibits spontaneous rat oocyte maturation. Endocrinology. Vol. 126, No. 3, pp. 1504-1508, ISSN 1945-7170

Tsukagoshi, H., Shimizu, Y., Kawata, T., Hisada, T., Shimizu, Y. \& Iwamae, S. (2001). Atrial natriuretic peptide inhibits tumor necrosis factor-alpha production by interferongamma-activated macrophages via suppression of p38 mitogen-activated protein kinase and nuclear factor-kappa B activation. Regulatory Peptides. Vol. 99, No. 1, pp. 21-29, ISSN 0167-0115 
Tung, K., Setiady, Y, Samy, E., Lewis, J. \& Teuscher, C. (2005). Autoimmune ovarian disease in day 3-thymectomized mice: the neonatal time window, antigen specificity of disease suppression, and genetic control.Current Topics in Microbiology and Immunology. Vol. 293, pp. 209-247, ISSN 0070-217X

Turvey, S. \& Broide, D. (2010). Innate immunity. Journal of Allergy and Clinical Immunology. Vol. 125, pp. 24-32, ISSN 0091-6749

Van Kasteren, Y., von Blomberg, M., Hoek, A., de Koning, C., Lambalk, N., van Montfrans, J., Kuik, J. \& Schoemaker, J. (2000). Incipient ovarian failure and premature ovarian failure show the same immunological profile.American Journal of Reproductive Immunology. Vol. 43, No. 6, pp. 359-66, ISSN 1600-0897

Vangelov, I., Dineva, J., Nikolov, G., Lolov, S. \& Ivanova, M. (2005). Antibodies against granulosa luteinized cells and their targets in women attending IVF program. American Journal of Reproductive Immunology. Vol. 53, No. 2, pp. 106-12, ISSN 16000897

Vangelov, I., Dineva, J., Nikolov, G., Gulenova, D. \& Ivanova, I. (2008). Relationship among Anti-granulosa Luteinized Cells Antibodies, Apoptosis of Granulosa Luteinized Cells, Levels of TNF-a and IFN-g in Follicular Fluids of Infertile Women. Comptes rendus de l'Acade'mie bulgare des Sciences. Vol. 61, No. 3, pp. 341348, ISSN 1310-1331

Vangelov, I., Dineva, J., Nikolov, G., Gulenova, D. \& Ivanova, M. (2006). Anti- granulosa cell antibodies in follicular fluids and their impact on the response to controlled ovarian hyperstimulation / fertilization rate. Comptes rendus de l'Acade'mie bulgare des Sciences. Vol. 59, No.11, pp. 1191-1196, ISSN 1310-1331

Vangelov, I., Dineva, J., Nikolov, G., Gulenova, D. \& Ivanova, M. (2009). Impact of Follicular Cytokines (TNF- $\alpha$, IFN- $\gamma$ and Apoptosis of Human Granulosa Luteinized Cells (GLCs) on the Results after Controlled Ovarian Hyperstimulation (COH) and in vitro Fertilization (IVF) in Women with Ovarian Factor of Infertility. Comptes rendus de l'Acade'mie bulgare des Sciences. Vol. 62, No. 9, pp. 1169-1176, ISSN 1310-1331

Vollmar, A. \& Schulz, R (1995). Expression and differential regulation of natriuretic peptides in mouse macrophages. Journal of Clinical Investigation. Vol. 95, No. 6, pp. 2442-2450, ISSN 0021-9738

Vollmar, A., Mytzka, C., \& Schulz, R. (1988). Atrial natriuretic peptide in bovine corpus luteum. Endocrinology. Vol. 123, No. 2, pp. 762-767, ISSN 1945-7170

Vujovic, S. (2009). Aetiology of premature ovarian failure. Menopause International. Vol. 15, pp. 72-75, ISSN 1754-0461

Welt, C., Falorni, A., Taylor, A., Martin, K. \& Hall JE. (2005). Selective theca cell dysfunction in autoimmune oophoritis results in multifollicular development, decreased estradiol, and elevated inhibin B levels.Journal of Clinical Endocrinology $\mathcal{E}$ Metabolism. Vol. 90, No. 5, pp. 3069-76, ISSN 1945-7197

Zhang, M., Tao, Y., Zhou, B., Xie, H., Wang, F., Lei, L., Huo, L., Sun, Q. \& Xia, G. (2005). Atrial natriuretic peptide inhibits the actions of FSH and forskolin in meiotic maturation of pig oocytes via different signalling pathways. Journal of Molecular Endocrinology. Vol. 34, No. 2, pp. 459-472, ISSN 1479-6813 
Zhang, X., Xu, H., Jiang, Y., Yu, S., Cai, Y., Lu, B., Xie, Q. \& Ju, T. (2008). Influence of dexamethasone on mesenteric lymph node of rats with severe acute pancreatitis. World Journal of Gastroenterology. Vol. 14, No. 22, pp. 3511-3517, ISSN 1007-9327 


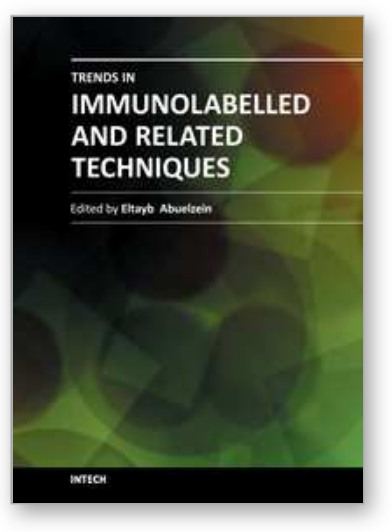

\author{
Trends in Immunolabelled and Related Techniques \\ Edited by Dr. Eltayb Abuelzein
}

ISBN 978-953-51-0570-1

Hard cover, 360 pages

Publisher InTech

Published online 27, April, 2012

Published in print edition April, 2012

The book is coined to provide a professional insight into the different trends of immunoassay and related techniques. It encompasses 22 chapters which are grouped into two sections. The first section consists of articles dealing with emerging uni-and-multiplex immunolabelled methods employed in the various areas of research. The second section includes review articles which introduce the researchers to some immunolabelled techniques which are of vital significance such as the use of the conjugates of the Staphylococcus aureus protein "A" and the Streptococcus Spps. protein "G" in immunolabelled assay systems, the use of bead-based assays and an overview on the laboratory assay systems. The book provides technological innovations that are expected to provide an efficient channel for developments in immunolabelled and related techniques. It is also most useful for researchers and post-graduate students, in all fields, where immunolabelled techniques are applicable.

\title{
How to reference
}

In order to correctly reference this scholarly work, feel free to copy and paste the following:

Ivailo Vangelov, Julieta Dineva, Krassimira Todorova, Soren Hayrabedyan and Maria D. Ivanova (2012). Ovarian Biomarkers in Infertility, Trends in Immunolabelled and Related Techniques, Dr. Eltayb Abuelzein (Ed.), ISBN: 978-953-51-0570-1, InTech, Available from: http://www.intechopen.com/books/trends-inimmunolabelled-and-related-techniques/ovarian-biomarkers-in-infertility

\section{INTECH}

open science | open minds

\author{
InTech Europe \\ University Campus STeP Ri \\ Slavka Krautzeka 83/A \\ 51000 Rijeka, Croatia \\ Phone: +385 (51) 770447 \\ Fax: +385 (51) 686166 \\ www.intechopen.com
}

\author{
InTech China \\ Unit 405, Office Block, Hotel Equatorial Shanghai \\ No.65, Yan An Road (West), Shanghai, 200040, China \\ 中国上海市延安西路65号上海国际贵都大饭店办公楼 405 单元 \\ Phone: +86-21-62489820 \\ Fax: $+86-21-62489821$
}


(C) 2012 The Author(s). Licensee IntechOpen. This is an open access article distributed under the terms of the Creative Commons Attribution 3.0 License, which permits unrestricted use, distribution, and reproduction in any medium, provided the original work is properly cited. 